\title{
Constitutional Theory Transformed
}

\author{
Stephen M. Griffin ${ }^{\dagger}$
}

Theories of constitutional change should try to see the Constitution as a whole, ${ }^{1}$ to understand how all three branches of government have contributed to the course of constitutional development in the United States. ${ }^{2}$ Among recent theorists of constitutional change, Bruce Ackerman deserves great credit for highlighting the importance of this issue and stressing the need to consider the relationships among all the branches of government during three great constitutional moments: Founding, Reconstruction, and the New Deal. ${ }^{3}$

While Ackerman is primarily interested in exploring the implications of constitutional change for constitutional law, I am interested in what this means for constitutional theory. ${ }^{4}$ Using the New Deal as my focus, I will

$\dagger$ Professor of Law, Tulane University. I acknowledge the helpful research assistance of Richard S. Dukes, Jr. I am grateful to Barry Friedman, Richard D. Friedman, Michael Klarman, Sandy Levinson, Michael Dorf, and Keith Whittington for commenting on an earlier version. I would like to thank the enterprising editors of The Yale Law Journal for agreeing to sponsor a symposium on constitutional change and, then, seeing the project through. This essay is dedicated to the memory of my father, Clifford S. Griffin, Professor of American History at the University of Kansas from 1959 to 1997.

1. Bruce Ackerman and Lawrence Lessig are two prominent theorists who have undertaken the project of understanding the Constitution as a whole. See 1 BRUCE ACKERMAN, WE THE People: Foundations (1991); 2 BRUCE ACKerman, We The PEOPLE: TRANSFormations (1998); RESPONDING TO IMPERFECTION: THE THEORY AND PRACTTCE OF CONSTTTUTIONAL AMENDMENT (Sanford Levinson ed., 1995); Lawrence Lessig, Fidelity and Constraint, 65 FORDHAM L. REV. 1365 (1997); Lawrence Lessig, Translating Federalism: United States v. Lopez, 1995 SUP. CT. REv. 125 (1995); Lawrence Lessig, Understanding Changed Readings: Fidelity and Theory, 47 STAN. L. REV. 395 (1995) [hereinafter Lessig, Understanding]; Lawrence Lessig, Fidelity in Translation, 71 TEx. L. REv. 1165 (1993) [hereinafter Lessig, Fidelity]; Symposium, Fidelity in Constitutional Theory, 65 FORDHAM L. REV. 1247 (1997).

I set out my own theory of constitutional change in STEPHEN M. GRIFFI, AMERICAN CONSTITUTIONALISM: FROM THEORY TO POLITICS 9-19, 26-58, 68-87 (1996).

2. It would thus be unwise to assume at the outset that a single branch of government, such as the Supreme Court, has been the sole source of important constitutional changes. It is unlikely that the Court has initiated or is responsible for all of the significant changes that have occurred with respect to the political branches. It seems intuitive, for example, that the nation's presidents have had something to do with changes in their office. For a recent brief treatment of constitutional changes in the presidency, see Cass R. Sunstein, An Eighteenth Century Presidency in a Twenty-First Century World, 48 ARK. L. REV. 1 (1994).

3. See 1 ACKERMAN, supra note 1;2 ACKERMAN, supra note 1.

4. My theory of constitutional change does not begin with the Court, but rather with the idea that all of the branches are likely to have initiated significant constitutional changes at one time or 
argue in this essay that the new concern with constitutional change has the potential to transform American constitutional theory. I argue for an historicist constitutional theory that is at odds with the interpretive approach of most constitutional lawyers and scholars. ${ }^{5}$ Within an historicist framework, the theory of constitutional change is prior to the task of constitutional interpretation. ${ }^{6}$

This perspective on constitutional change is inspired in part by the methodology of "historical institutionalism" in political science. ${ }^{7}$ Historical institutionalism is often called a "state-centered" approach because it takes the concept of the state seriously and focuses on its halting evolution through American history. Perhaps the most important contribution of historical institutionalism has been its emphasis on the autonomy of the state. ${ }^{8}$ As historian Alan Brinkley describes, the main thesis of this state-

another. Further, I do not begin with the Court in a methodological sense; that is, I do not assume that the kind of legalistic interpretation that characterizes the Court's opinions necessarily prevails in the other branches. I see no reason to assume that constitutional change in the political branches is fundamentally a matter of interpreting the Constitution. Change may happen through interpretation, but it also may not. Since ordinary political change often happens as a result of power struggles, electoral victories, interest group pressure, and so on, it seems unlikely that changes in the constitutional structure of the political branches would be driven solely by legalistic interpretation. Justices Kennedy and O'Connor recently made this point in United States v. Lopez, 514 U.S. 549, 577-78 (1995) (opinion of Kennedy, J., concurring).

5. Here and elsewhere in this essay, I use "interpretive" and "interpretation" in the very specific sense of legal interpretation. I do not mean to refer to the much different debate of whether the social sciences should be pursued through an interpretive method.

6. How is the idea of "change" to be understood? What counts as a change? Some might imagine that I must use an originalist notion of change, according to which change in the Constitution is to be measured against a baseline of the Framers' intent. In this and in my earlier work, however, I am not using an originalist baseline, but an historicist one. The baseline for determining whether a constitutional change has occurred is not a relatively discrete set of statements by important members of the Founding generation issued during the period surrounding the adoption of the Constitution, as well as statements by Framers of its subsequent amendments. It is rather the historical context in which those statements were made. More specifically, the baseline for assessing change is composed of the institutional structures and state capacities created by the Constitution. We can study constitutional change by observing the continuities and discontinuities as these structures develop over time.

7. For representative works, see BRINGING THE STATE BACK IN (Peter B. Evans et al. eds., 1985); JAMES G. MARCH \& JOHAN P. OLSEN, REDISCOVERING INSTITUTIONS: THE ORGaNIZATIONAL BASIS OF POLITICS (1989); ERIC A. NORDLINGER, ON THE AUTONOMY OF THE DEMOCRATIC STATE (1981); MARTIN SHEFTER, POLITICAL PARTIES AND THE STATE: THE AMERICAN HISTORICAL EXPERIENCE (1994); and STEPHEN SKOWRONEK, BUILDING A NEW AMERICAN STATE: THE EXPANSION OF NATIONAL ADMINISTRATIVE CAPACITIES, 1877-1920 (1982). See also Karen Orren \& Stephen Skowronek, Institutions and Intercurrence: Theory Building in the Fullness of Time, in POLITICAL ORDER 111 (Ian Shapiro \& Russell Hardin eds., 1996); Polity Forum: Institutions and Institutionalism, 28 POLITY 84 (1995); Rogers M. Smith, Science, Non-Science, and Politics, in THE HISTORIC TURN IN THE HUMAN SCIENCES 119 (Terrence J. McDonald ed., 1996); Rogers M. Smith, Still Blowing in the Wind: The American Quest for a Democratic, Scientific Political Science, 126 DAEDALUS 253 (1997) [hereinafter Smith, Still Blowing in the Wind].

8. The very idea of an autonomous national state presupposes the capacity to make effective decisions and have them enforced. See, e.g., KENNETH FINEGOLd \& THEDA SKOCPOL, STATE AND PARTY IN AMERICA'S NEW DEAL 50-59 (1995). In the case of the American state, this 
centered approach is that " $[\mathrm{t}]$ he state and the institutions surrounding it ... are themselves crucial factors in determining the outcome of political struggles, indeed often more influential than social forces or the efforts of popular interest groups." 9 The point is that the state does not simply provide the arena in which various interests struggle for dominance. The state also writes the rulebook, polices the field, decides the winners, or even changes the game in the middle of play. The structure of the state and, especially, the decisions made before the players take the field, have a real and continuing influence on policy outcomes. ${ }^{10}$

My point of departure is how constitutional law accounts for the New Deal, one of the most crucial periods of constitutional change in American history. I initially confront the best known, most widely accepted, and most implausible account of constitutional change during the New Deal-that it involved no real change as such, but was simply a restoration of the previous wisdom of the Marshall Court. Ackerman notes that lawyers tell themselves a story about the New Deal that "denies that anything deeply creative was going on. This view of the 1930s is obtained by imagining a Golden Age in which Chief Justice Marshall got things right for all time by propounding a broad construction of the national government's lawmaking authority." "What I will call the restoration thesis, or restorationism, is still very much alive. ${ }^{12}$

Ackerman is correct to assert that the restoration thesis serves as a primary way for contemporary constitutionalists to integrate the New Deal into the larger story of American constitutionalism. But the importance of

capacity has been acquired over time, leading to the focus, characteristic of historical institutionalism, on state building. See, e.g., SKOWRONEK, supra note 7.

At the most abstract level, historical institutionalists speak of "weak" or "strong" states. Strong states are relatively autonomous of civil society, while weak states are dependent on societal interests to make decisions and implement policies. There are a number of more specific opposing terms that go along with the terms weak or strong. Weak states can be so because their departments and agencies are fragmented instead of coordinated. Or state agencies can be decentralized at different levels of government rather than centralized at the national level. Further, states have various capacities for action. A state with a competent, adequately funded bureaucracy, for example, is more likely to have the infrastructural capacity "to penetrate society and to organize social relations." JOHN A. HALL \& G. JOHN IKENBERRY, THE STATE 13 (1989). With this richer vocabulary, we can reach a more precise understanding of the development of state institutions, which then enables us to achieve a more dynamic view of the course of constitutional change. See generally Stephen D. Krasner, Approaches to the State: Alternative Conceptions and Historical Dynamics, 16 COMP. POL. 223 (1984).

9. ALAN BRINKLEY, THE END OF REFORM: NEW DEAL LIBERALISM IN RECESSION AND WAR 11 (1995).

10. See generally Krasner, supra note 8. For a discussion in the New Deal context, see FINEGOLD \& SKOCPOL, supra note 8, at 50-59.

11. 2 ACKERMAN, supra note 1, at 42; see also 2 ACKERMAN, supra note 1 , at 259.

12. This was demonstrated by the critical reaction to Ackerman's argument. See, e.g., Charles Fried, Foreword: Revolutions?, 109 HARV. L. REv. 13 (1995); Laurence H. Tribe, Taking Text and Structure Seriously: Reflections on Free-Form Method in Constitutional Interpretation, 108 HARV. L. REV. 1223 (1995). 
the restoration thesis goes far beyond this. It is a key prop in maintaining traditional, ahistorical approaches to constitutional law and theory. In effect, the thesis asserts that our constitutional world is meaningfully related to the world of the early republic, the world of James Madison, Alexander Hamilton, and John Marshall. The thesis maintains continuity with the past, reassuring scholars that there is an unbroken American constitutional tradition. It thus prevents scholars from gaining a more perspicuous view of the process of constitutional change by denying that overwhelmingly significant changes have occurred since 1787 in the structure of American government.

Before we can gain a better understanding of the process of constitutional change, then, the restoration thesis must be debunked. I do this in Part I by setting out the restoration thesis as it has been advocated by scholars and the Supreme Court and critiquing it for being implausible as a matter of history. It is important to understand that I do not criticize restorationism for being an incorrect interpretation of the Constitution or for misunderstanding original intent. My critique is offered from an historicist perspective. After all, what leads scholars to defend restorationism? The problem here is an old one in legal scholarship-the failure to pay attention to historical context. This is where the methodology of historical institutionalism is useful. Its focus on the development of state institutions provides the context that is missing every time legal scholars invoke McCulloch v. Maryland,$^{13}$ Gibbons v. Ogden,${ }^{14}$ or some other Marshall Court decision as a precursor of the kind of government we have today.

The problems with restorationism are not confined to its understanding of the Marshall Court. Precisely because it is an interpretive rather than a historicist response to the New Deal, restorationism fails to understand the new constitutional order that was created by the Great Depression. I describe the constitutional changes of the New Deal along four dimensions: American democracy, constitutional doctrine, constitutional institutions such as the presidency and federalism, and American constitutional ideology.

My own theory of constitutional change, presented in the final section of Part I, is intended to avoid not only the mistakes of restorationism, but of all similar interpretive or legalistic theories. It therefore does not offer an alternative interpretation of the Constitution, but an historicist, statecentered perspective on the development of constitutional institutions. I argue that the attempt of the Founding generation to create a permanent constitutional order founded on enduring principles produced an impasse once the national state became truly activist in response to the Great

13. 17 U.S. (4 Wheat.) 316 (1819).

14. 22 U.S. (9 Wheat.) 1 (1824). 
Depression. The difficulty of formal amendment under Article $\mathrm{V}$ forced most constitutional change "off-text." Further, most of this change was not expressed in a legalistic manner through the development of Supreme Court precedent, but rather occurred in the course of ordinary political change. To track the changes brought on by the activist state, both during the New Deal and after, we must have a way of specifying the rules, practices, and institutions that operate as the functional equivalent of the rules contained in the text of the Constitution. Again, historical institutionalism is helpful. By directing our attention to the development of state institutions, it frees us from having to rely solely on constitutional amendments and Court precedents as markers of change. We can then view our constitutional order as a whole and ask new questions about the changing relationships among constitutional institutions in the post-New Deal period.

My critique of restorationism thus cuts very deeply into traditional approaches prevailing in constitutional law and theory. It implies that no conventional theory of constitutional interpretation can justify the constitutional changes that occurred during the New Deal. Since these changes are usually thought to constitute the very foundation of the contemporary regulatory-welfare state, the stakes are high. At issue is our understanding of the origins of the current arrangement of state institutions and of their legitimacy in a constitutional sense. The critique of restorationism thus suggests that in order to understand our constitutional world we must transform constitutional theory by turning our attention from interpreting the Constitution to understanding the relationship between the Constitution and the historical development of state institutions.

I explore the idea of a transformed constitutional theory in Part II. I begin by examining Ackerman's theory of transformative amendment, as recently advanced in We The People: Transformations. ${ }^{15}$ Ackerman's theory of constitutional change is similar to my own in that he recognizes the need to adopt an historicist approach, ${ }^{16}$ although this has not been recognized by many of Ackerman's critics. ${ }^{17}$ But Ackerman attempts to account for constitutional change within a framework that remains ultimately legalistic. Ackerman argues that Reconstruction and the New Deal gave birth to unconventional amendments that have the same legal status as amendments made through Article V. His theory has trouble coming to grips with the more political aspects of constitutional change,

15. See 2 ACKERMAN, supra note 1.

16. On the role of history and historicism, see 1 ACKERMAN, supra note 1, at 16-33; and GRIFFIN, supra note 1 at $164-69$.

17. See, e.g., Terrance Sandalow, Abstract Democracy: A Review of Ackerman's We The People, 9 CONST. COMMENTARY 309 (1992) (reviewing 1 ACKERMAN, supra note 1); Suzanna Sherry, The Ghost of Liberalism Past, 105 HARV. L. ReV. 918 (1992) (same); Richard A. Posner, This Magic Moment, THE NEw REPUBLIC, Apr. 6, 1998, at 32 (reviewing 2 ACKERMAN, supra note 1). 
especially how that change is produced by ordinary political struggles. For all its historical sophistication, Ackerman's theory is advanced in a legalistic mode that is not helpful in understanding twentieth century constitutional change.

I then argue that the main theories of constitutional interpretation are not historicist theories, no matter what claims they make to historical backing. I begin by describing some specific criticisms historians make of the use of history in constitutional interpretation. These criticisms may be familiar because they have been employed in the debate over originalism. But my purpose in emphasizing a few particular criticisms is to make the largely overlooked point that they apply to all theories of constitutional interpretation, originalist or not. This is because all the theories of constitutional interpretation normally discussed by scholars accept an ahistorical view about the role that the constitutional principles of the early republic can and should play in the complex democracy of the present. The emphasis in these theories-characteristic of American constitutionalism from the beginning-is on how the fundamental principles adopted by the Founding generation can solve contemporary constitutional problems. This approach is completely implausible from an historicist perspective. ${ }^{18}$

Suppose constitutional theory did take historicism seriously. What result? In the final section of Part II, I provide an account of what an historicist, contextualized constitutional theory would look like. A contextualized constitutional theory would involve pairing normative constitutional theory with the study of the development of the fundamental institutions, practices, and rules that structure American politics. The ahistorical, anachronistic questions that are often the focus of interpretive theory-such as whether the Framers endorsed the contemporary institution of judicial review or the right of privacy-would be avoided. We would then have the ability to pose and answer new questions about the structure of American government that have not received a proper hearing in mainstream constitutional theory.

18. In a widely noted article, Robert Gordon argued that historicism, which he defined as "the recognition of the historical and cultural contingency of law," still had not been absorbed by legal scholars because it was a threat to the standard ways of doing legal scholarship. Robert W. Gordon, Historicism in Legal Scholarship, 90 YALE L.J. 1017, 1017 (1981); see also Robert W. Gordon, The Past as Authority and as Social Critic: Stabilizing and Destabilizing Functions of History in Legal Argument, in THE HISTORIC TURN IN THE HUMAN SCIENCES 339 (Terrence J. McDonald ed., 1996) [hereinafter Gordon, The Past as Authority]. Gordon contended that the evasion of this threat had limited the "intellectual options and imaginative range" of legal scholarship. Gordon, Historicism in Legal Scholarship, supra, at 1017. Although Gordon used some examples drawn from constitutional law, he did not explore in any detail the consequences of his thesis for constitutional theory. I believe that Gordon was largely correct. 


\section{THE NEW DEAL “RESTORATION” AND THE THEORY OF CONSTITUTIONAL CHANGE}

\section{A. Restorationism Reconsidered}

The restoration thesis holds that decisions of the Marshall Court, particularly Gibbons v. Ogden ${ }^{19}$ and McCulloch v. Maryland ${ }^{20}$ provided a complete constitutional justification for the legislation enacted during the New Deal. Constitutional controversy over legislation enacted by Congress centered on the Commerce Clause, providing that Congress has the power "[t]o regulate Commerce with foreign Nations, and among the several States, and with the Indian Tribes." ${ }^{21}$ One particular paragraph in Gibbons interpreting this clause proved irresistible for partisans of the New Deal. Here, Chief Justice Marshall defined the commerce power as "the power to regulate; that is, to prescribe the rule by which commerce is to be governed." ${ }^{22}$ Marshall continued, "[t]his power, like all others vested in Congress, is complete in itself, may be exercised to its utmost extent, and acknowledges no limitations, other than are prescribed in the constitution." ${ }^{23}$ Then, in his most suggestive remark, Marshall stated:

If, as has always been understood, the sovereignty of Congress, though limited to specified objects, is plenary as to those objects, the power over commerce with foreign nations, and among the several States, is vested in Congress as absolutely as it would be in a single government, having in its constitution the same restrictions on the exercise of the power as are found in the constitution of the United States. $^{24}$

The word "plenary" was especially comforting to those searching for constitutional bases for New Deal legislation. To New Dealers, the word implied that Congress had a broad power to regulate the national economy as it saw fit. This argument was made, not just after hours or in political speeches, but in the legal briefs submitted to the Supreme Court to justify New Deal legislation. ${ }^{25}$ In a famous article, Robert Stern (who worked in

19. 22 U.S. (9 Wheat) 1 (1824).

20. 17 U.S. (4 Wheat.) 316 (1819).

21. U.S. CONST. art. I, \& 8, cl. 3.

22. Gibbons, 22 U.S. at 196.

23. Id.

24. Id. at 197.

25. See PETER H. IRONS, THE New DEAL LAWYERS 137-38 (1982). Irons himself appears to accept the restoration thesis. See id. at 47 . For a Court opinion that emphasizes the plenary nature of the power established in Gibbons, see Hodel v. Virginia Surface Mining \& Reclamation Ass'n, 452 U.S. 264, 276 (1981). 
the Solicitor General's office throughout the Roosevelt administration) argued that New Deal legislation regulating national economic activity was justified under "the fundamental concepts which guided those men who prepared the Constitution and to the principles which the Supreme Court has professed since the days of John Marshall." ${ }^{26}$ As Peter Irons has shown, government lawyers cited Gibbons repeatedly in litigation as a precedent that justified New Deal legislation. ${ }^{27}$ In the wake of the Court's 1937 shift, Attorney General (soon to be Justice) Robert Jackson summarized the constitutional meaning of what had occurred: "[T]he unifying principle running through all of our constitutional litigations has been the recognition that the Constitution contemplated a really effective government. It has been in the nature of a Constitutional Renaissance-a rediscovery of the Constitution itself." 28

While government lawyers and constitutional scholars have advanced the restoration thesis, its most influential proponent has been the Supreme Court itself. When the Court began consistently upholding the validity of New Deal legislation after 1937, Gibbons provided the foundation for the Court's approach to the Commerce Clause. In United States v. Darby, ${ }^{29}$ Justice Stone cited Gibbons prominently in upholding the Fair Labor Standards Act and overruling Hammer v. Dagenhart. ${ }^{30}$ In relying on the paragraph from Gibbons quoted above, Stone referred to "the plenary power conferred on Congress by the Commerce Clause" ${ }^{31}$ and contended that, Hammer excepted, this had been the consistent policy of the Court since Marshall's time. ${ }^{32}$ In Wickard v. Filburn, ${ }^{33}$ the case that completed the Court's shift away from its pre-1937 jurisprudence, Justice Jackson echoed the arguments made in his book and again invoked Gibbons, claiming that "[a]t the beginning Chief Justice Marshall described the federal commerce power with a breadth never yet exceeded." ${ }^{34}$ Jackson characterized Court opinions upholding broad interpretations of the commerce power as "bring[ing] about a return to the principles first enunciated by Chief Justice Marshall in Gibbons v. Ogden ...." 35

26. Robert L. Stern, That Commerce Which Concerns More States Than One, 47 HARV. L. REV. 1335, 1337 (1934).

27. See IRONS, supra note 25 , at $92-93,137-38,295$.

28. ROBERT H. JACKSON, THE STRUGGLE FOR JUDICIAL SUPREMACY: A STUDY OF A CRISIS IN AMERICAN POWER POLITICS xiv-xv (1941) (emphasis added). For further evidence of the prominence of the restoration thesis in the late 1930 s and 1940s, see PAUL L. MURPHY, THE CONSTITUTION IN CRISIS TimeS, 1918-1969, at 167-68 (1972). See also Hugh Evander Willis, Gibbons v. Ogden Then and Now, 28 KY. L.J. 280, 286, 302 (1940).

29. 312 U.S. 100 (1941).

30. 247 U.S. 251 (1918).

31. 312 U.S. at 115.

32. See id.

33. 317 U.S. 111 (1942).

34. Id. at 120 .

35. Id. at 122 . 
Commerce Clause decisions that came after the close of the New Deal era echoed the theme of restoration set out in Darby and Wickard. In Heart of Atlanta Motel v. United States, ${ }^{36}$ the case which upheld Title II of the Civil Rights Act of 1964, the Court quoted several long passages from Gibbons $^{37}$ and stated that although "conditions of transportation and commerce have changed dramatically," " nonetheless "the principles which we apply today are those first formulated by Chief Justice Marshall in Gibbons v. Ogden...." ${ }^{39}$ Finally, in Perez v. United States, ${ }^{40}$ the Court quoted Gibbons as encapsulating a broad view of the commerce power. ${ }^{41}$ The Court continued, "[d]ecisions which followed departed from that view; but by the time of United States v. Darby ... and Wickard v. Filburn... the broader view of the Commerce Clause announced by Chief Justice Marshall had been restored." 42

Restorationism is not simply an enthusiasm confined to the Court or to the 1930s and 1940s. As Ackerman argues, it remains the leading organizing idea that contemporary lawyers and judges employ in understanding how the New Deal fits into the larger narrative of the American constitutional tradition. ${ }^{43}$ This is nowhere better illustrated than by the reaction of some leading Harvard doctrinalists to Ackerman's criticism of restorationism. The responses of Charles Fried and Laurence Tribe contain more than a whiff of the idea that the post-1937 Court was simply returning to the path laid down by Chief Justice Marshall. With respect to the Marshall Court, Fried states that its decisions "gave significant support to a broad reading of the extent of the national power over the economy," 44 and thus, of course, to the New Deal itself. Tribe writes that "the Supreme Court's New Deal shifts were matters of legitimate if controversial constitutional interpretation. They simply did not entail any sort of architectural alteration that would require a textual change in the Constitution." 45

The restoration thesis allows constitutional lawyers to maintain a narrative of continuity when telling the tale of the American constitutional tradition. The constitutional structures and precedents of today are represented as having more than just a family resemblance to the

36. 379 U.S. 241 (1964).

37. See id. at 254-55.

38. Id. at 251 .

39. Id.

40. 402 U.S. 146 (1971).

41. See id. at 150-51.

42. Id. at 151 .

43. See, e.g., Paul R. Benson, JR., The Supreme Court and the Commerce Clause, 1937-1970, at 57, 64-65, 90, 94-95, 101 (1970); BERNARD SCHWARTZ, THE SUPREME COURT: CONSTITUTIONAL REVOLUTION IN RETROSPECT 28-38 (1957).

44. Fried, supra note 12, at 33 .

45. Tribe, supra note 12 , at 1295. 
institutions and understandings of the Founding generation. The possibility that this makes little sense from an historical point of view is not raised because the restoration thesis is more of an "as if" belief than a conclusion based on a serious examination of the world of the early republic. Once a concern for historical context enters the picture, the restoration thesis collapses.

Recent historical scholarship on the Marshall Court has cast serious doubt on the restoration thesis simply by placing the Court in the context of its own time. In his comprehensive history of the later Marshall Court, G. Edward White opens his discussion of such cases as Martin v. Hunter's Lessee ${ }^{46}$ Cohens v. Virginia ${ }^{47}$ McCulloch v. Maryland, ${ }^{48}$ and Gibbons v. Ogden ${ }^{49}$ by saying that these rulings have "often been loosely characterized and sometimes patently misunderstood." ${ }^{50} \mathrm{He}$ continues, "[t]he cases have often been identified as decisions promoting 'nationalism,' but ... [t]he 'nationalism' inherent in those decisions was not a nationalism in the modern sense of support for affirmative plenary federal regulatory power; the Court's posture can more accurately be described as a critique of reserved state sovereignty." 51

White does note that twentieth-century scholars have been more than willing to describe the Court in nationalistic terms, but "to the extent that the cases took on additional implications, such as the implication that the economic and political growth of the nation would be accompanied by a growth in the regulatory powers of the federal government, the Marshall Court cannot fairly be identified with those implications." ${ }^{52}$ The Marshall Court was simultaneously trying to carve out a place for itself and the federal government as a whole and defend itself from political attack. ${ }^{53}$ Under these conditions, Chief Justice Marshall's theory of broad federal power articulated in McCulloch and Gibbons was "more of a preservationist theory in its emphasis than a theory designed to foster an affirmative federal regulatory presence." ${ }^{54}$

46. 14 U.S. (1 Wheat) 304 (1816).

47. 19 U.S. (6 Wheat.) 264 (1821).

48. 17 U.S. (4 Wheat.) 316 (1819).

49. 22 U.S. (9 Wheat.) 1 (1824).

50. G. Edward White, The Marshall Court and Cultural Change, 1815-1835, at $486(1988)$.

51. Id.

52. Id. at 487.

53. See 1 ACKERMAN, supra note 1 , at 62 .

54. WHITE, supra note 50, at 519. The most recent biographies of Marshall and Justice Joseph Story agree with this assessment. See R. KENT NEWMYER, SUPREME COURT JUSTICE JOSEPH STORY: STATESMAN OF THE OLD REPUBLIC 148-49 (1985); JEAN EDWARD SMITH, JOHN MARShall: DEFINER OF A NATTON 445 (1996); see also Michael Les Benedict, Preserving Federalism: Reconstruction and the Waite Court, 1978 SUP. Cr. REv. 39, 42-44 (1979). 
Herbert Johnson concurs in his own recent study of the Marshall Court. ${ }^{55} \mathrm{He}$ argues that " $[t]$ he Court's emphatic rejection of the compact theory of Union ... marked it as a force for national unity. ... On the other hand, the Marshall Court justices never conceived that plenary federal power would be as pervasive as it has become in twentieth-century America." ${ }^{56}$ Charles Hobson, the editor of Marshall's papers, argues with respect to $\mathrm{McCulloch}$ that it should "not be understood as a prescient anticipation of the modern liberal state, in which a federal government of vastly augmented powers has assumed primary responsibility for regulating the economy and promoting social welfare." 57 The "nationalism" of McCulloch "is more accurately defined in negative or defensive terms .... The opinion purported not to enhance the powers of the federal government but to enable that government to exercise its powers effectively and to prevent state encroachments upon its legitimate operations." 58 Marshall certainly "did not intend to suggest that Congress, in addition to its delegated powers, could tap a vast reservoir of other powers that were not expressly granted but could be implied because Congress was the legislative branch of the national government." 59

With respect to Gibbons, Howard Gillman has recently pointed out that the opinion itself contains clear indications that Marshall could never accept the kind of broad reading of federal power advanced by the restorationists. ${ }^{60}$ Marshall showed that he believed in a bright line between interstate and intrastate commerce by saying that the power of Congress to regulate does not extend to "commerce, which is completely internal, which is carried on between man and man in a State, or between different parts of the same

55. See Herbert A. JOHNSON, THE ChIEF JUSTICESHIP OF JOHN MARSHALl, 1801-1835, at 73-74 (1997).

56. Id. at 73 (footnote omitted).

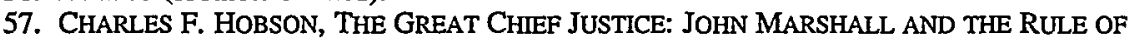
LAW 123 (1996).

58. $I d$.

59. Id. (footnote omitted). With respect to Gibbons, Hobson notes that while it "has often been cited as a landmark judicial precedent for extensive national power . . . the principal significance of Gibbons lay not so much in building up and centralizing federal power as in circumscribing state power." Id. at 139 .

60. Gillman's article is part of his exchange with Robert Lowry Clinton and Wallace Mendelson, who defend the traditional restorationist position. For the progress of this debate, see Robert Lowry Clinton, Judicial Review, Nationalism, and the Commerce Clause: Contrasting Antebellum and Postbellum Supreme Court Decision Making, 47 POL. RES. Q. 857 (1994); Howard Gillman, The Struggle over Marshall and the Politics of Constitutional History, 47 POL. RES. Q. 877 (1994); Robert Lowry Clinton, John Marshall's Federalism: A Reply to Professor Gillman, 47 POL. RES. Q. 887 (1994); Wallace Mendelson, John Marshall and the Sugar TrustA Reply to Professor Gillman, 49 POL. RES. Q. 405 (1996); Howard Gillman, More on the Origins of the Fuller Court's Jurisprudence: Reexamining the Scope of Federal Power over Commerce and Manufacturing in Nineteenth-Century Constitutional Law, 49 POL. RES. Q. 415 (1996); and Wallace Mendelson, Nullification via Dual Federalism: A Second Response to Professor Gillman, 49 POL. RES. Q. 439 (1996). 
State, and which does not extend to or affect other States." ${ }^{11}$ Further, in discussing state inspection and health laws, Marshall remarked that while they "may have a remote and considerable influence on commerce," ${ }^{62}$ they cannot be based on any power to regulate commerce. Why? Because "[t]hey act upon the subject before it becomes an article of foreign commerce, or of commerce among the States .... No direct general power over these objects is granted to Congress; and, consequently, they remain subject to State legislation." " ${ }^{63}$ Marshall thus implies that any product goes through a series of stages (such as production or manufacturing) before it can become an article of interstate commerce subject to congressional regulation. This further implies, of course, that Congress may not regulate products in these pre-commerce stages. This is fatal to the kind of regulatory power the New Dealers claimed for the federal government on the basis of Gibbons.

While these conclusions may seem surprising, these historians are not interested in undermining the New Deal. Instead, they want to understand what the Marshall Court meant in the circumstances that existed in early nineteenth-century America. In those circumstances, the fight over the nature and limits of federal regulatory power was not about whether to establish a powerful welfare state. ${ }^{64}$ On Marshall's side, at least, it was an effort simply to establish the legitimacy of the federal courts and the federal government as a whole; an effort to win respect for the national government from the states.

Restorationism asserts a certain relationship between decisions of the Marshall Court and the governmental structure of the early republic. Marshall was a "nationalist" and decisions of his Court confirmed that the federal government had broad powers to develop the American economy and regulate it in order to achieve ends legitimate under the Constitution. The historical works just reviewed make it clear that none of the Justices of the Marshall Court shared this vision. More important, examining the structure of the early national state makes it clear that no one in antebellum America could have conceived of a New Deal-style role for the national government in regulating the economy. Historical institutionalism shows the limits of relying on general terms such as "nationalist," "activist," and "regulation" to describe the kind of state that existed during Marshall's era, the New Deal, or our own period. ${ }^{65}$

61. Gibbons v. Ogden, 22 U.S. (9 Wheat.) 1, 194 (1824).

62. Id. at 203.

63. Id.

64. For an account that supports the position that the adoption of the Constitution established a very limited set of powers for the national government, see JACK N. RAKOVE, ORIGINAL MEANINGS: POLITICS AND IDEAS IN THE MAKING OF THE CONSTITUTION 177-202 (1996).

65. See 1 ACKERMAN, supra note 1 , at 62. 
McCulloch and Gibbons were decided against the background of what is usually termed the Jacksonian era in American politics. This era was not characterized by a steady accretion of power by the federal government, as is often implied by restorationist accounts that focus on the Supreme Court. In fact, one of the chief characteristics of the Jacksonian era was a sharp movement away from dreams of national development guided by a beneficent state. Moreover, throughout the entire antebellum period, the national state was extremely weak and simply unable to shoulder any of the tasks putatively assigned to it by the Marshall Court.

The weakness, indeed incompetence, of the national state during this period is a theme common to both political scientists and historians. Whether we consult the older studies of Leonard White on American public administration, ${ }^{66}$ the insightful work of James Sterling Young on how the government operated (or failed to operate) in Washington, ${ }^{67}$ or the more recent work of Stephen Skowronek, ${ }^{68}$ scholars in different academic fields and using different methodological approaches all agree that the antebellum national state often barely had a pulse. ${ }^{69}$

In Skowronek's influential formulation, the nineteenth-century American state was one of "courts and parties." system and political parties were the only institutions capable of coordinating government action. In the absence of a federal bureaucracy that had the infrastructural capacity to penetrate to local levels of government, the federal courts and the network of state parties had the ability to address issues of importance, distribute government benefits, and organize citizens for politics. As Charles Bright notes, "[t]he federal state was institutionally weak throughout the [nineteenth century], and it was getting relatively weaker after $1830 \ldots$ Under the Jacksonian

66. See LEONARD D. WhITE, THE FEDERALISTS: A STUDY IN ADMINISTRATIVE HISTORY (1948); LEONARD D. WHITE, THE JACKSONIANS: A STUDY IN ADMINISTRATIVE HISTORY 18291861 (1954); LEONARD D. WHITE, THE JEFFERSONIANS: A STUDY IN ADMINISTRATIVE HISTORY $1801-1829$ (1951).

67. See JAMES STERLING YOUNG, THE WASHINGTON COMMUNITY 1800-1828 (1966).

68. See SKOWRONEK, supra note 7.

69. As historian Charles Sellers describes:

Except in matters of diplomacy and war, [the federal government's] only direct services to citizens were the lightly used postal system, the federal courts, a National Road, and scattered lighthouses and navigational aids.... In 1815 the President paid out of his own pocket the single secretary who assisted him; the Attorney General had neither clerk nor office; the Supreme Court convened for two months a year in a Capitol Hill boarding house; and during the summer only the clerks and bureau chiefs remained in the muggy capital to keep the wheels of state slowly tuming.

ChARLES SELLERS, THE MARKET REVOLUTION: JACKSONIAN AMERICA 1815-1846, at 36-37 (1991).

70. SKOWRONEK, supra note 7, at 24. 
presidencies, powers accumulated at the national level by federalist statemakers were given up again." 71

One of the great political dramas of the Jacksonian era was the rejection of the "American System" of federal government support for roads, canals, and internal development put forward by Henry Clay, John Quincy Adams, John C. Calhoun, and many others. ${ }^{72}$ When put into practice, however, the desire for improvements that could bind the nation together turned out to pit section against section and state against state. President Jackson killed the American System, thinking that it was better to "abjure developmental powers altogether than to see them subserve, as they always did, the interests of the privileged against the unprivileged, the few against the many.... Government's 'true strength,' said Jackson in 1832, 'consists in leaving individuals and States as much as possible to themselves." 73

In light of these developments, it cannot be credibly maintained that Supreme Court decisions of this period established the legitimacy of widespread national government intervention in the economic order. American politics was running in the opposite direction. The Jacksonian state was not being built up, but torn down in favor of the maximum possible release of energy by the enterprising American people. ${ }^{74}$ As we have seen, the language of Gibbons and other Marshall Court decisions was not really to the contrary. From the Court's perspective, its task was not to suggest a policy agenda for a rising national state. It was rather to preserve a limited sphere of federal power against insistent attempts by the states to dismantle it altogether. ${ }^{75}$ This task was entirely consistent with the tentative quality of the nascent American state.

At this point I must take notice of a conceptual complication in this apparently straightforward argument. Does a historicist account of the Marshall Court really refute restorationism or simply change the subject? Restorationism, after all, is an interpretation of the Constitution and Court precedents, put forward in a serious way by knowledgeable lawyers and justices, and supported by perfectly conventional arguments. One might think it misguided, but showing where it goes wrong would surely involve

71. Charles C. Bright, The State in the United States During the Nineteenth Century, in STATEMAKING AND SOCIAL MOVEMENTS 121, 121 (Charles Bright \& Susan Harding, eds.) (1984).

72. See, e.g., DANIEL FELlER, THE JACKSONIAN PROMISE: AMERICA 1815-1840, at 53-60, 66-75, 162-68; SELLERS, supra note 69, at 70-84, 149-52, 312-31. Calhoun, of course, eventually tumed against the American System and the federal power it represented. See SELLERS, supra, at 305-06.

73. FELLER, supra note 72 , at 168 .

74. See id. at 167.

75. See Leslie Friedman Goldstein, State Resistance to Authority in Federal Unions: The Early United States (1790-1860) and the European Community (1958-94), 11 STUD. AM. POL. DEV. 149 (1997); Mark A. Graber, The Passive-Aggressive Virtues: Cohens v. Virginia and the Problematic Establishment of Judicial Power, 12 CONST. COMMENTARY 67 (1995). 
advancing yet another interpretation. It is therefore important to appreciate that the historicist argument I have just made is not an interpretation of the Constitution as ordinarily understood.

All interpretations of the Constitution tend to abstract from historical context. They do so partly to avoid being bogged down in unnecessary detail, but also to retain the capability to resolve the contemporary issues to which they are addressed. But a given interpretation cannot abstract entirely from historical context without losing its status as an interpretation of the Constitution rather than of some other historical document. Constitutional interpretation is always backward-looking in this sense. It draws on the past in order to provide legal authority to the present. Even as it abstracts from historical context, then, constitutional interpretation is dependent on it for its status as law. If the authority sought in the past is not there to be found, the interpretation is debunked.

That is what the foregoing argument accomplished with respect to restorationism. Its status as law has been debunked because the context it presumes did not exist in the antebellum republic. I debunked it, moreover, by employing an historicist argument rather than a competing interpretation. This raises the possibility that the same argument could be made of any interpretive attempt to justify the New Deal. This raises the stakes a bit higher. The issue is not the abandonment of some outmoded theory pursued by a few naive New Deal lawyers. It is rather whether any interpretive argument can suffice to justify the constitutional changes that occurred during the New Deal and after. Pursuing this line of inquiry involves coming to a better understanding of just what constitutional changes occurred after Franklin Roosevelt took office in 1933.

\section{B. The New Deal as a Constitutional Revolution}

The New Deal was indeed a constitutional revolution, one that can be traced in three dimensions of constitutional change: the doctrines of constitutional law, the institutions of American government, and the ideology of American constitutionalism. A fourth distinct dimension to the New Deal is that it represented a change in American democracy. This extremely important constitutional change is the key to understanding all the others and also makes clear why the New Deal was not simply a significant but incremental development. After all, didn't independent regulatory agencies exist before the New Deal? Wasn't national regulatory power clearly recognized in certain areas, such as over the railroads and 
monopolies? Hadn't Theodore Roosevelt and Woodrow Wilson articulated new conceptions of the presidency? ${ }^{76}$

All this is true but beside the point. To see why, we need to remind ourselves of one obvious feature of the New Deal-it was a response to a crisis. ${ }^{77}$ The Great Depression was one of the most serious political and economic crises in American history. ${ }^{78}$ Such crises create unique opportunities for state building, and FDR and the Democratic Congress exploited the opportunity to the extent they were able. But the President and Congress were able to go as far as they did because they had the backing of the democratic authority provided by some of the greatest electoral victories in American politics. The American people confirmed over and over again, particularly in the presidential elections of 1936 and 1940, that they wanted the government to have the constitutional power necessary to alleviate the Depression and to prevent future economic disasters. ${ }^{79}$

As Louis Seidman and Mark Tushnet have suggested, at the base of these New Deal electoral mandates lay a public belief that the national government should be held accountable not only when it acts, but when it fails to act-such as when it fails to respond to a national economic emergency. ${ }^{80}$ Once the federal government was held responsible by the American people for its failures to act, the entire idea of limited constitutional government was thrown into question. A government comprised of politicians and officials who know that they will be held accountable for failing to prevent significant harms to the American public is a government that is necessarily affirmative rather than limited-a government that constantly seeks out problems with which citizens are concerned in order to "solve" them and address their needs generally. It is a welfare state in a literal sense.

These democratic electoral mandates thus created an entirely different dynamic for the national state-one that had no precedent in American history. Never before had there been a consistent electoral mandate for the assumption of permanent national power over the entire economy. Certainly, before the New Deal, the federal government was involved in the regulation of economic activity. But it was a question of the regulation of

76. See, e.g., Larry Kramer, What's a Constitution For Anyway? Of History and Theory, Bruce Ackerman and the New Deal, 46 CASE W. RES. L. REV. 885, 916-24 (1996).

77. Historical institutionalists emphasize the importance of crises for state-building efforts. See Charles Bright \& Susan Harding, Processes of Statemaking and Popular Protest, in STATEMAKING AND SOCIAL MOVEMENTS, supra note 71, at 1, 14; SKOWRONEK, supra note 7, at 10-12.

78. See, e.g., JoHN A. Garraty, THE Great Depression (1986); WILliam E. LEUCHTENBURG, FRANKLIN D. ROOSEVELT AND THE NEW DEAL, 1932-1940 (1963).

79. There is an obvious affinity here with the argument that Ackerman makes with respect to the New Deal. See 2 ACKERMAN, supra note 1, at 279-382.

80. See louis Michael SEIDMAN \& MaRK V. Tushnet, REMNANTS of Belief: CONTEMPORARY CONSTITUTIONAL ISSUES 49-71 (1996). 
this or that industry, such as the railroads, or this or that specific harm, such as impure food or monopolies. The Great Depression was a crisis in which it became necessary to contemplate regulation of the entire economy, all economic activity, no matter what its form. It is not surprising that the only precedent New Dealers could find to justify such a course of action was the kind of command and control government regulation of the economy exerted during World War $\mathrm{I}^{81}$

The new dynamic created by the provision of democratic authority for economic intervention provided the impetus and justification behind the New Deal revolution in the constitutional order. Besides the often discussed changes in constitutional doctrine overseen by the Supreme Court, there were two additional dimensions to the revolution that were just as important: changes in the structure of state institutions, and the death of a constitutional ideology that had important ties to the republican ideology of the early republic. In each dimension, the changes were fundamental rather than incremental because, although each change had its progenitors, the democratic backing for state intervention created a new, permanently different context for the exercise of state authority. I will discuss each of these three dimensions in turn.

The New Dealers were going beyond piecemeal regulatory efforts to formulate a plan for reviving the entire economy. Any measures necessary in this revival would be constitutionally justifiable, at least as far as they were concerned. But this kind of comprehensive planning ran afoul of several specific lines of Supreme Court precedent. The Court did not hold unconstitutional everything done in the name of the New Deal. Nevertheless, what was unconstitutional devastated the general purpose of the New Deal一to assume responsibility for addressing what was wrong with the American economy as a whole. The New Dealers won several different electoral mandates to do just that. The course set by the Court in cases such as Railroad Retirement Board v. Alton Railroad Co. ${ }^{82}$ A.L.A. Schechter Poultry Corp. v. United States, ${ }^{83}$ United States v. Butler, ${ }^{84}$ and Carter v. Carter Coal Co. ${ }^{85}$ therefore guaranteed a political conflict with the New Deal. ${ }^{86}$

81. See William E. LeuchtenBuRg, The FDR YeARs: ON RoOSEvelt aND His Legacy 35-75 (1995).

82. 295 U.S. 330 (1935) (invalidating the Railroad Retirement Act).

83. 295 U.S. 495 (1935) (invalidating the National Industrial Recovery Act).

84. 297 U.S. 1 (1936) (invalidating the Agricultural Adjustment Act).

85. 298 U.S. 238 (1936) (invalidating the Guffey Coal Act).

86. This story has been told many times and lately a dispute has broken out over how the "switch" occurred. For contrasting views, compare BARRY CUSHMAN, RETHINKING THE NEW DEAL COURT: THE STRUCTURE OF A CONSTITUTIONAL REVOlUTION (1998), and Richard D. Friedman, Switching Time and Other Thought Experiments: The Hughes Court and Constitutional Transformation, 142 U. PA. L. REv. 1891 (1994), with WILLIAM E. LeUCHTENBURG, THE SUPREME COURT REBORN: THE CONSTITUTIONAL REVOLUTION IN THE AGE OF ROOSEVELT 
The fundamental departure made by New Deal legislation in terms of doctrine had to do with the sheer scale of the control FDR and Congress wished to exercise over the economy. The National Industrial Recovery Act (NIRA) contemplated state control of all prices, wages, and conditions of labor in the United States. ${ }^{87}$ While there were pre-New Deal precedents giving the federal government the power to influence certain prices, particular wages, and some working conditions, the idea of total control had never entered the Court's mind and had no basis in the constitutional thought of the Founding generation.

According to Kenneth Finegold and Theda Skocpol, if the National Recovery Administration (NRA) and the Agricultural Adjustment Act (AAA) had succeeded, "the United States might have emerged from the Great Depression as a centralized system of politically managed corporatist capitalism. The state would have been directly involved in planning price and production levels and in allocating income shares to capitalists, farmers, and workers." 88 This was not exactly the kind of limited republican order envisaged in the 1787 Constitution. In reaction to this radical policy shift, a majority of the Court committed itself to a point of view that divided legislation affecting the economy into distinct categories. If the main purpose and effect of the legislation was to regulate production

(1995), and David A. Pepper, Against Legalism: Rebutting an Anachronistic Account of 1937, 82 MARQ. L. REV. 63 (1998).

For other important discussions see MrCHAEL E. PARRISH, ANXIOUS DECADES: AMERICA IN PROSPERTTY AND DEPRESSION, 1920-1941, at 364-76 (1992); Michael Ariens, A Thrice-Told Tale, or Felix the Cat, 107 HARV. L. REV. 620 (1994); John W. Chambers, The Big Switch: Justice Roberts and the Minimum-Wage Cases, 10 LaBOR HIsT. 44 (1969); Richard D. Friedman, A Reaffirmation: The Authenticity of the Roberts Memorandum, or Felix the Non-Forger, $142 \mathrm{U}$. PA. L. REV. 1985 (1994); Michael E. Parrish, The Great Depression, the New Deal, and the American Legal Order, 59 WASH. L. REv. 723 (1984) [hereinafter Parrish, The Great Depression]; Michael E. Parrish, The Hughes Court, the Great Depression, and the Historians, 40 HisTORIAN 286 (1978) [hereinafter Parrish, The Hughes Court].

I have serious reservations about Cushman's narrowly doctrinal account of the Court's 1937 switch. While space does not permit setting out my objections in detail, it is important to point out that many reputable scholars have in effect taken the position that purely doctrinal explanations of the votes of Chief Justice Hughes and Justice Roberts in the various New Deal cases are implausible because they took inconsistent positions. Their positions were inconsistent with respect to their allegiance to broad constitutional values such as federalism, as set forth in pre1937 decisions. The most plausible explanation for their votes is therefore that they changed their minds about the relative importance of various constitutional values. The context for their change in view was: (1) the hostile, bipartisan reaction to Morehead v. Tipaldo, 298 U.S. 587 (1936), which held unconstitutional a New York statute mandating a minimum wage for women and minors (only relevant to Roberts); (2) FDR's overwhelming victory in the 1936 election; and (3) FDR's Court-packing plan (only relevant to some 1937 decisions). Cushman's tendentious distinction between "internal" or doctrinal explanations and "external" or political explanations means that he never comes to grips with the most persuasive version of the "external" account, one that is, in fact, an internal explanation to the extent that it focuses on the motives of Hughes and Roberts. See CUSHMAN, supra, at 4.

87. Cf. 2 ACKERMAN, supra note 1 , at 286-89 (discussing NIRA's replacement of market capitalism with a corporatist structure).

88. FINEGOLD AND SKOCPOL, supra note 8, at 20. 
or conditions of labor, then the legislation did not regulate commerce and, in addition, violated the powers reserved to the states under the Tenth Amendment. ${ }^{89}$ The role of the Court in making such distinctions was to preserve the constitutional order so as to avoid a centralized government. ${ }^{90}$

The Court thus made impossible the kind of close regulation of production and government involvement in labor relations that was one of the hallmarks of New Deal. From National Labor Relations Board v. Jones \& Laughlin Steel Corp. ${ }^{91}$ in 1937 to United States v. Darby ${ }^{92}$ and Wickard $v$. Filburn, ${ }^{93}$ the Court did not merely reverse course and abandon the categories it had tried to maintain. It also articulated a new standard of deference to Congress that ensured it would be very difficult to challenge any legislation enacted to regulate some aspect (no matter how local it first appeared) of the national economy. Whether the Court was following the 1936 election returns, reacting to FDR's Court-packing plan, simply changing as its membership changed after 1937, or some combination of all three, political forces outside the walls of the Marble Temple drove the transformation of constitutional doctrine that resulted. The Court's opposition to important forms of regulatory legislation engendered political opposition and split the legal elite. The political and legal circumstances produced by the Court's long opposition to various forms of regulatory legislation made it easy for FDR to recruit new Justices who could be counted on to support the New Deal.

The two most obvious changes in state institutions accomplished by the New Deal were made with respect to the presidency and the structure of American federalism. ${ }^{94}$ The power of the presidency was enhanced

89. See Railroad Retirement Bd. v. Alton R.R. Co., 295 U.S. 330, 367-68 (1935); Butler, 297 U.S. at 63-64, 68-78; Carter Coal, 298 U.S. at 297-310.

90. In A.LA. Schechter Poultry Corp. v. United States, 295 U.S. 495 (1935), for example, Chief Justice Hughes stated:

In determining how far the federal government may go in controlling intrastate transactions upon the ground that they "affect" interstate commerce, there is a necessary and well-established distinction between direct and indirect effects. ... If the commerce clause were construed to reach all enterprises and transactions which could be said to have an indirect effect upon interstate commerce, the federal authority would embrace practically all the activities of the people, and the authority of the state over its domestic concerns would exist only by sufferance of the federal government.

.... The distinction between direct and indirect effects of intrastate commerce must be recognized as a fundamental one, essential to the maintenance of our constitutional system. Otherwise, as we have said, there would be virtually no limit to the federal power and for all practical purposes we should have a completely centralized government.

Id. at 546, 548.

91. 301 U.S. 1 (1937).

92. 312 U.S. 657 (1941).

93. 317 U.S. 111 (1942).

94. Since I have provided more detail on the presidency and federalism in my book, my discussion here is brief. I should note, however, that the presidency was affected just as much by 
dramatically by Roosevelt's leadership during the Great Depression. The presidency became a new kind of constitutional office, offering the potential for a president to surmount the separation of powers and become the de facto head of the federal government, if not the nation as a whole. ${ }^{95}$ Historian Michael Parrish's summary echoes the conclusions of many scholars: "[FDR's] mastery of the radio, his superb political skills, and the Executive Reorganization Act of 1939 enormously enhanced the prestige of the presidency. With Roosevelt's tenure the White House became the focus of popular dissatisfaction with the nation's economy, foreign policy, and moral tone." 96

The Great Depression also forced a significant alteration in American federalism. ${ }^{97}$ To an extent that is difficult to appreciate today, state governments were largely ineffectual in responding to the armies of the poor and unemployed that required assistance..$^{98}$ This inability to respond had a constitutional dimension in that many state constitutions made it very difficult for state governments to do anything. ${ }^{99}$ This left a vacuum of power that was filled at the national level. The national state of the New Deal was built by assuming tasks that local and state governments had previously shouldered alone. The result was a complex system in which there were a few programs for which the national government was solely responsible, many more programs for which the national and state governments shared responsibility (typically with the federal government providing funding and the states providing administration) and some policies that the federal government encouraged the states to adopt on their own through use of grants-in-aid and other carrots and sticks. The federal government led the way, but the states were an indispensable partner.

Finally, the constitutional revolution of the New Deal had an important ideological dimension. The central assumptions of American legal and constitutional thought were antithetical to the principles the New Dealers

the changes that occurred in the Cold War as the developments during FDR's terms in office. See GRIFFIN, supra note 1, at 81-85.

95. See LeUCHTENBURG, supra note 86, at 1-34; SIDNEY M. MIIKIS, THE PRESIDENT AND THE PARTIES: THE TRANSFORMATION OF THE AMERICAN PARTY SYSTEM SINCE THE NEW DEAL 150-51 (1993).

96. See Parrish, The Great Depression, supra note 86 , at 727 (internal citations omitted).

97. See id. For a recent treatment from a doctrinal perspective, see Stephen Gardbaum, New Deal Constitutionalism and the Unshackling of the States, 64 U. CHI. L. REV. 483 (1997). Gardbaum's analysis is useful to the extent that he reminds us that the end of the "no go zone" in due process jurisprudence necessarily meant that the states came out of the New Deal with greatly expanded regulatory powers. But Gardbaum's article also shows the inherent limits of doctrinal history: He never assumes an institutionalist perspective, that is, he never tells us what the states did with their new powers. As I suggest in the text, at least with respect to unemployment and poor relief, they were not able to do very much.

98. See James T. Patterson, The New Deal and the States: Federalism in TRANSITION (1969).

99. See GRIFFIN, supra note 1 , at $41-42$. 
had developed to justify their proposals. These assumptions included the following: ${ }^{100}$

First, that some economic regulatory measures were beyond the power of legislatures to enact. An important example was legislation passed to benefit a particular class of citizens. ${ }^{101}$

Second, that individuals and corporations had vested property rights that originated in the Constitution and could not be violated absent compelling reasons. ${ }^{102}$

Third, that government measures could not have the redistribution of property as their primary object - there could be no "taking the property of A and giving it to B." 103

Fourth, that state governments retained sovereignty in the federal system as equals of the national government, as guaranteed by the Tenth Amendment. ${ }^{104}$

Fifth, that the role of the federal government should be strictly limited and that any additional duties taken on should be of a temporary nature (as during a war) or should be understood as clear exceptions to the normal rule of non-intervention.

Of course, these assumptions overlapped. The important point is that they were understood to be interwoven with the Constitution itself.

The New Deal ran counter to all of them. Given the emergency conditions created by the Depression and the democratic public authority provided by their electoral victories, New Dealers simply did not pay much attention to any of these assumptions. ${ }^{105}$ The emergency justified ignoring

100. This list of assumptions is an extremely compressed summary of recent historical work on the constitutional ideology that prevailed between the Civil War and the New Deal. See, e.g., CUSHMAN, supra note 86, at 6; HOWARD GILLMAN, THE CONSTITUTION BESIEGED: THE RISE AND DEMISE OF LOCHNER ERA POLICE POWERS JURISPRUDENCE (1993); Benedict, supra note 54; see also JAMES W. ELY, JR., THE CHIEF JUSTICESHIP OF MELVILLE W. FULLER, 1888-1910 (1995); OWEN M. FISS, TROUBLED BEgINNINGS OF THE MODERN STATE, 1888-1910 (1993); MORTON J. HORIVITZ, THE TRANSFORMATION OF AMERICAN LAW, 1870-1960 (1992); HERBERT HOVENKAMP, ENTERPRISE AND AMERICAN LAW 1836-1937 (1991); WILLIAM E. NELSON, THE ROOTS OF AMERICAN BUREAUCRACY, $1830-1900$ (1982); WILLIAM M. WIECEK, THE LOST WORLD OF CLASSICAL LEGAL THOUGHT (1998); Michael Les Benedict, Laissez-Faire and Liberty: A Re-Evaluation of the Meaning and Origins of Laissez-Faire Constitutionalism, 3 LEGAL HIST. REV. 293 (1985); Stephen A. Siegel, Lochner Era Jurisprudence and the American Constitutional Tradition, 70 N.C. L. REV. 1 (1991).

101. See, e.g., GILLMAN, supra note 100.

102. See, e.g., WIECEK, supra note 100, at 124-26.

103. See id. at 132 .

104. See Benedict, supra note 54, at 41-42. This is the doctrine of "dual federalism" or "states' rights." Benedict comments that "[t]hose who advocated broad expansion of the national role from the Progressive to the New Deal eras ... . argued that this doctrine of dual federalism had subverted the nationalistic principles expounded by the Marshall Court. But in reality, most Americans had accepted dual federalism as implicit in those principles." Id. at 42.

105. Peter Irons notes, for example, that some NRA lawyers found even the strong restorationist argument advanced by Robert Stern to be too timid. See IRONS, supra note 25, at 9293. 
these no doubt outmoded ideas, based as they were on notions of a static, unchanging Constitution. New Deal legal thinkers publicized the arrival of the dynamic, living Constitution, which changed as social and economic needs demanded. ${ }^{106}$ It was absurd to think that constitutional ideals formed in an age without modern transportation, communications, and monopolistic corporations should rule in the more complex environment of the 1930s. It is difficult to overstate how completely the New Dealers were alienated from these assumptions, once an unquestioned part of the American constitutional tradition.

The conclusive proof that the New Deal embodied a constitutional revolution relates to the belief of the New Dealers that the Depression constituted a serious national emergency. The idea that the emergency justified New Deal legislation competed with restorationism as a legal argument offered in the courts. ${ }^{107}$ But the rationale of emergency also served as a much broader political and constitutional justification for the New Deal. Arguably, it was FDR's justification of choice. Even before he gained the Democratic nomination in 1932, he invoked the idea of emergency and the analogy to war to prepare his audience for the kind of activist government that would be necessary. ${ }^{108}$ In his inaugural address, FDR made the wartime analogy explicit. FDR claimed that the American people understood "that if we are to go forward, we must move as a trained and loyal army." 109 He offered a pledge to "bind upon us all as a sacred obligation with a unity of duty hitherto evoked only in time of armed strife." 110 If Congress failed this challenge, however, and was unable to pass needed legislation, "I shall ask the Congress for the one remaining instrument to meet the crisis-broad Executive power to wage a war against the emergency, as great as the power that would be given to me if we were in fact invaded by a foreign foe." 111

Historians have noted the importance of the wartime analogy to the justification of the New Deal. ${ }^{112}$ FDR and his supporters called on the experience with command and control government during World War I

106. See, e.g., Howard Gillman, The Collapse of Constitutional Originalism and the Rise of the Notion of the 'Living Constitution' in the Course of American State-Building, 11 STUD. AM. POL. DEv. 191 (1997); G. Edward White, The "Constitutional Revolution" as a Crisis in Adaptivity, 48 HASTINGS L.J. 867 (1997).

107. See IRONS, supra note 25 , at $52-54,93$.

108. See Franklin D. Roosevelt, "A Concert of Action, Based on a Fair and Just Concert of Interests," Address at Jefferson Day Dinner, St. Paul, Minn. (April 18, 1932), in 1 THE PUBLIC PAPERS AND ADDRESSES OF FRANKLIN D. ROOSEVELT 627, 631 (1938).

109. Franklin D. Roosevelt, Inaugural Address (March 4, 1933), in 2 THE PUBLIC PAPERS AND ADDRESSES OF FRANKIIN D. ROOSEVELT, 11, 14 (1938) (address of March 4, 1933).

110. Id.

111. Id. at 15.

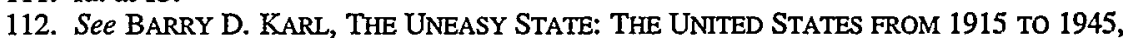
at 119-21 (1983); LEUCHTENBURG, supra note 86, at 35-75; Michal R. Belknap, The New Deal and the Emergency Powers Doctrine, 62 TEX. L. REV. 67 (1983). 
with several purposes in mind: to prepare the American people for what might be necessary, to formulate a plan of action, and to justify the farreaching government intrusions into the economy necessary to address the Depression. Yet the rationale of emergency and the use of the wartime analogy point toward a troubling feature of the New Deal revolution. Much like the Civil War, the New Deal discredited a specific legal ideology without replacing it with a broader political justification for consistent government activism. ${ }^{13}$ The wartime analogy purchased justification at a price. FDR and his successors could obtain decisive action from Congress only by invoking the kind of authority that was appropriate in an emergency where the survival of the country was at stake. But this kind of authority could not be sustained. The wartime analogy implied that presidential authority and the measures taken under it would always be temporary. ${ }^{114}$

From a constitutional perspective the question that must be asked is why the emergency rationale was necessary. From a restorationist point of view, FDR should have simply declared his allegiance to the principles of McCulloch and Gibbons. ${ }^{115}$ But FDR never embraced restorationism or any other approach that resembled what we now call originalism. Old constitutional rationales were unavailable and new ones were slow to form. That New Dealers employed the emergency rationale thus tends to discredit not only restorationism, but any theory of constitutional change that represents the American constitutional tradition as a narrative of continuity. ${ }^{116}$ Like the Civil War, the New Deal marked a sharp break, a discontinuity in American constitutionalism. The New Deal created a hole in the constitutional world. ${ }^{117}$

In addition, the rationale of emergency and the appeal to the kind of government power exercised during World War I show clearly why the New Deal was not an incremental development in the history of American state building. ${ }^{118}$ If it were really the case that a competent national state had been established in the Progressive era, no such argument would have been necessary. The national state would have already had the institutions and justifications required to deal with the Great Depression. Of course this was not the case. ${ }^{119}$ The crucial element of state capacity was missing. ${ }^{120}$ It

113. In the Civil War, it was the doctrine of state sovereignty and its corollaries of interposition, nullification, and secession that were discredited. See Benedict, supra note 54.

114. See GRIFFI, supra note 1, at 81-85; KARL, supra note 112.

115. Roosevelt did say in his inaugural address that the Constitution was adequate to meet the crisis. This remark was made, however, within the framework provided by the wartime analogy, which should have been unnecessary had Roosevelt really accepted some version of restorationism.

116. See, e.g., Fried, supra note 12; Tribe, supra note 12.

117. See GILlMAN, supra note 100, at 201-02.

118. But see Kramer, supra note 76, at 916-24.

119. As Barry Karl notes, 
had to be supplied not simply through developing new agencies and infusing Washington with a new cadre of administrative experts, but through fundamentally new constitutional and political justifications.

The different dimensions of change arising from the New Deal pose a key challenge for any attempt to understand constitutional change. Of course, none of these changes occurred through the amendment process specified in Article V of the Constitution. It should be clear by now that the Supreme Court did not have the primary role in initiating or carrying through all of the dimensions of change. Even with respect to changes in constitutional doctrine, the Court was more controlled by events and political circumstances than it was their master. It therefore does not make much sense to understand the dimensions of change as occurring through the legalistic process of constitutional interpretation. This opens the door to an approach that is more historicist, political, and state-centered.

\section{A Political Theory of Constitutional Change}

The shock of the New Deal revolution created two distinct spheres in the complex political practice we call American constitutionalism. ${ }^{21}$ The first and smaller sphere was that of the legalized Constitution, the part of constitutionalism under the nominal control of the Supreme Court. In this sphere, constitutional change did proceed more or less as it is traditionally understood; that is, it occurred not only through formal amendments but also through the Court's development of precedent. So in stressing a more general perspective on constitutional change, I certainly do not mean to deny that the Court enforces the Constitution and adapts it to changing conditions. Ultimately, however, it does so only with the permission or acceptance of the political branches. The sphere of the legalized Constitution is necessarily much smaller than the sphere of American constitutionalism as a whole.

In the larger sphere of what might be called the political Constitution, constitutional change did not occur through formal amendment, Supreme

[T] he mechanisms for giving the federal government control over a centralized, nationalized industrial system simply did not exist. A skilled federal bureaucracy was not available, and, even had it been, it is doubtful that a managerial army would have been acceptable to most Americans, accustomed as they were to looking on active government as a threat.

KARL, supra note 112, at 119; see also GRIFFIN, supra note 1, at 80-81 (noting that Congress had long been reluctant to give up control over the federal bureaucracy).

120. Finegold and Skocpol argue that in a few particular areas, such as agriculture, there was substantial capacity to administer the programs of the New Deal. See FINEGOLD \& SKOCPOL, supra note 8, at 58-59. However, in general, Finegold and Skocpol agree with the majority of scholars that the U.S. national state was weak prior to the New Deal. See id. at 53-57.

121. In this Section, I summarize the theory of constitutional change that is presented in much greater detail in GRIFFIN, supra note 1, at 26-58. 
Court decisions, or legalistic interpretations of the constitutional text. Instead, it occurred through ordinary political change. Here, the President and Congress directed constitutional development. This development, of course, did not end with the New Deal. It continued through World War II, the Cold War, and the extraordinary period of government activism and regulation that began with President Johnson's Great Society. ${ }^{122}$

There is a sense in which the limits on the legally enforceable Constitution were programmed into the constitutional system from the beginning. This did not become obvious, however, until the national state became a truly activist state in the New Deal. In the era in which the activity of the national state was extremely limited (which existed for most of American history), one could imagine that the entire constitutional structure was being guided by decisions of the Supreme Court. Consider, however, the nature of the agency required to keep up with constitutional change once the state becomes activist. Since any state action has the potential to change or violate the Constitution, the entire state must be subject to scrutiny. The agency in charge of maintaining the Constitution must constantly monitor the flow of policy change. It must stand ready to intervene at any moment to prevent unconstitutional action.

The Supreme Court has never possessed this kind of power. Early on, the Court decided that it must indeed act as a court if it was to have any legitimacy at all. This move was successful - the Court established a base of power around the idea that in reviewing state and national legislation, it was performing a function well suited to courts. ${ }^{123}$ This required the Court to wait for litigation to develop before it could decide any constitutional question. It drew a line between law and politics and placed itself on the law side of the boundary. Political questions could not be entertained. ${ }^{124}$ The Court thus could not control the total flow of constitutional change.

In the context of the activist state, the Supreme Court would have to be the most powerful branch of government in order successfully to monitor the flow of constitutional change. All actions of the national state would have to pass the tests set by the Court. There could be no evasion of review, no unlitigated issues, and no political questions. Since it is inefficient to inform the other branches of the unconstitutionality of actions after they have already been taken, the Court would have to issue advisory opinions routinely. These are the sort of actions that would be necessary to make the sphere of the legalized Constitution coextensive with the sphere of the political Constitution.

122. See GRIFFIN, supra note 1 , at $81-87,194-201$.

123. See Marbury v. Madison, 5 U.S. (1 Cranch) 137 (1803).

124. See id. at 166-67. 
Nothing like this occurred during the New Deal or after. The Supreme Court responded to the advent of the activist national state and the new power of the presidency, not by increasing its own power, but by getting out of the way. ${ }^{125}$ How could it have been different? As long as the changes in view were approved by a large majority of the public, presidents could always find Justices who agreed with the implicit limits on the legalized Constitution. In any case, to keep up with the activist state, the Court would have had to abandon the idea that it was a court and create a new institutional order. Not only was there never any political support for doing this, but the option of becoming something other than a court and thus having to abandon the law-politics distinction never even occurred to the Justices or the legal elite on whose support they depended.

To illustrate this point further, what would have been required for the sphere of the legalized Constitution to keep up with the pace of constitutional change? How could the changes occurring during and after the New Deal have been deliberated about and legalized in a way that would preserve a meaningful link with the 1787 Constitution? There is only one answer within the structure of the Constitution-a constitutional convention. The only way to "adapt" the Constitution in a way that ensures the entire document is legally enforceable is by involving elites and the public in a common process that creates a new, settled constitutional order adequate to the demands of the twentieth century. ${ }^{126}$ It is ironic that this option is just the one most likely to be rejected by those who revere the Constitution and seek to maintain its legalized form.

The aspiration of the Founding generation to create a permanent constitutional order based on enduring principles thus produces something of an impasse when it is set in the context of the activist national state. Such a state produces a flow of continuous constitutional change that cannot be controlled by any court. The activist state creates a set of new, fundamental structuring rules, practices, and institutions that have the same function as those contained in the text of the Constitution, but without any pedigree in either Article V or judicial precedent. The parts of the Constitution not overseen by the Supreme Court on a regular basis begin to dissolve into the structure of the state. The text of the Constitution tells us less and less about

125. The exception, of course, is in the area of civil liberties and civil rights. Even here, however, most of the Court's jurisprudence concerned actions of the state governments, not the national government. Furthermore, in the new democratic context produced by the New Deal, it is a mistake to say simply that the Court responded by increasing its power to oversee the other branches in the area of rights. The question should rather be posed as follows: Why was it in the interest of the national state for the Court to handle these kinds of issues? For an interesting discussion, see Mark A. Graber, The Nonmajoritarian Difficulty: Legislative Deference to the Judiciary, 7 STUD. AM. POL. DEV. 35 (1993).

126. See the brief remarks to this effect in Lessig, Fidelity, supra note 1, at 1268. 
the way the government actually operates and what rules, practices, and institutions are key elements of the constitutional order.

In a polity with an old Constitution that has not been updated through amendments that respond to the activist state and cannot be updated through judicial precedents, seeing the Constitution as a whole necessarily involves taking proper account of constitutional change that has occurred outside conventionally accepted avenues. As I have been suggesting, the best way to do this is by employing an historical and institutional approach that focuses on the rules, practices, and institutions that are the functional equivalent of those in the Constitution. ${ }^{127}$ These rules may be informal (in the sense of not being enacted) or formal (expressed in statutes, regulations and so on). Since we cannot work from an authoritative text in the case of these functionally equivalent rules, we must use an interdisciplinary perspective to sift through history, politics, and key events to find those rules that have appeared most crucial to structuring policy processes and outcomes. The study of these rules can guide us in building a model of our present constitutional order that should enable us to better understand that order, anticipate future developments, and formulate proposals for improvement.

The hole that the New Deal created in the constitutional world is the gap between the historical world of the Founding generation and the very different world created by the need to respond to the crisis of the Depression. While the Founding generation had a number of years to consider the problems of the 1780 s and reflect on the proper design of constitutional institutions, Roosevelt did not have this luxury. During the New Deal the constitutional system had to be edited, as it were, on the fly. The scale and ad hoc character of this constitutional change make it extremely unlikely that any theory of constitutional interpretation can account for it. Restorationism clearly cannot. But the problems of restorationism extend to all interpretive theories. All of the theories of constitutional interpretation currently in the field maintain a link with the past through the text. None of them can account plausibly for the constitutional changes set in motion by the New Deal. ${ }^{128}$

If interpretive theories cannot be our guide to this new constitutional universe, how are we to proceed? In the next Part, I will explore how to

127. Hereinafter, just "rules."

128. This may appear to be an implausible conclusion, given that I have dealt only with restorationism. But restorationism is the theory that results from the most common modes of constitutional interpretation: appeals to text and intent. The other major approach to constitutional interpretation focuses on the abstract character of the text. See, e.g., RONALD DWORKIN, FREEDOM'S LAW: THE MORAL READING OF THE AMERICAN CONSTITUTION (1996). While Dworkin has not discussed the legitimacy of the New Deal, Lawrence Lessig has presented a Dworkin-like theory that attempts to justify the New Deal. I criticize Lessig's theory infra note 182. 
transform constitutional theory in order to better understand the Constitution we have.

\section{HISTORY, SCHOLARSHIP, AND CONSTITUTIONAL THEORY}

\section{A. Ackerman's Theory}

In different ways, both Ackerman and I are attempting to develop historicist theories of constitutional change. It is telling that this is one of the points on which Ackerman has been most misunderstood. Legal scholars have difficulty even recognizing historicist theories for what they are. To these scholars, historicist theories look "originalist" at best and nonsensical at worst. ${ }^{129}$ Before I launch into my critique of We The People: Transformations, I should therefore say that Ackerman deserves tremendous credit in three areas: (1) highlighting the importance of the general issue of constitutional change; (2) emphasizing the study of American constitutionalism as a series of regimes, ${ }^{130}$ which means concentrating on changes in all three branches of government over time; and (3) adopting an historicist approach to the different moments in constitutional history. ${ }^{131}$

In Transformations, Ackerman improves the general argument for his theory in several respects. He usefully contrasts his theory with that of "hypertextualist" readings of Article V that cannot account for the

129. See Kramer, supra note 76, at 915-17; Sherry, supra note 17, at 923-28.

130. See 1 ACKERMAN, supra note 1 , at 58-130.

131. See $1 \mathrm{id}$. at 16-33. Ackerman's historicism of course includes not only his treatment of Lochner, as I note below, but his rejection of restorationism.

Unfortunately, Ackerman's critics have largely missed these points, especially the last. This is shown by two common criticisms of Ackerman's first volume. One, advanced by Terrance Sandalow and others, was that Ackerman was trying to rehabilitate Lochner v. New York, 198 U.S. 45 (1905), one of the most criticized decisions of what Ackerman calls the "Middle Republic." To conventional scholars, this was heresy. See, e.g., Sandalow, supra note 17, at 33334. From their point of view, Lochner was wrong at the moment it was decided and there is no reasonable contemporary justification for the judicial philosophy that it represented. Ackerman, however, stated quite clearly that he wanted legal scholars to view Lochner in a "legally detached way," which is to say from an historicist point of view. 1 ACKERMAN, supra note 1, at 66 . Ackerman was trying to put Lochner in context, an Ackermanian context to be sure, but an historical context nonetheless. See $1 \mathrm{id}$. at 58-67, 99-103. From this perspective, it is pointless to condemn Lochner as wrong (or praise it as right). The task is to understand how the result and reasoning in Lochner was plausible within the context of its own time.

A second common criticism is that Ackerman's theory is difficult to implement because it gives judges the role of deciding when constitutional moments have occurred. See, e.g., Posner, supra note 17, at 34. Not only does this criticism misunderstand completely the thrust of Ackerman's theory, it demonstrates unwittingly the kind of Court-centered focus Ackerman labors to correct. Constitutional moments are the kind of events about which everyone tends to agree. Everyone recognizes that something has happened. The moment creates a new constitutional reality, as it were, and there is no real possibility of the Court doing anything else but ratifying it. 
questions surrounding Article $\mathrm{V}$, the legitimacy of the Reconstruction Amendments, or the New Deal. ${ }^{132}$ This is intended to put his critics on the defensive and may well succeed (if they pay attention to his specific historical evidence). Ackerman also makes it much clearer that he is not offering an originalist argument to justify his theory. In Foundations, this was left uncertain, despite Ackerman's appeal to historicism, because he employed a detailed argument from The Federalist to justify his theory. ${ }^{133}$ In Transformations, Ackerman makes it apparent that he is offering an historical and structural argument that attempts to show American citizens facing the same challenges every time they try to amend the Constitution in a fundamental (transformative) way. ${ }^{134}$

Ackerman situates his theory of constitutional change between two misguided alternatives. One is hypertextualism, the theory of the Article V literalists who believe the only way the Constitution can change is through Article V (and perhaps Supreme Court precedent). The other is the view that constitutional change outside of these normal legal means must be understood as a form of revolutionary politics that can only succeed or fail. ${ }^{135}$ In describing this latter alternative, Ackerman loads the dice somewhat by thinking only of what happens during truly significant episodes of constitutional change such as the Founding, Reconstruction, and the New Deal. The reasoning here is that because these moments are so epochal, the alternative to justifying them legally must be some sort of theory of revolutionary change which sees everything as "just politics." Ackerman does not consider the idea that the flow of constitutional change may be continuous, occurring through ordinary political struggles.

Ackerman understandably spends most of his time refuting the view that Article V settles how valid constitutional amendments can occur. As Ackerman notes, this is the theory that has the greatest acceptance among lawyers. ${ }^{136}$ And in both Foundations and Transformations, Ackerman takes pains to appeal to lawyers and judges, not just legal scholars. He remarks that "America is a legalistic country," 137 and clearly wants to produce a legal theory that can be used by lawyers and citizens, not just studied.

The problem here is that trying to turn unconventional constitutional change into "the functional equivalents of formal constitutional amendment" ${ }^{138}$ that have the same legal status as amendments adopted through Article $\mathrm{V}$ threatens the entire enterprise of the legalized

132. See 2 ACKERMAN, supra note 1, at 71-95.

133. See 1 ACKERMAN, supra note 1 , at 165-99.

134. See 2 ACKERMAN, supra note 1 , at $12,66-68$.

135. See 2 id. at $11-12$.

136. See 2 id. at 70, 115 .

137. 2 id. at 12 .

138. 2 id. at 26. 
Constitution. It opens the Constitution to political considerations and fluid arguments that appear arbitrary to doctrinalists and lack the security provided by Article $\mathrm{V} \cdot{ }^{139}$ In Transformations, Ackerman tries to convince mainstream scholars that his theory poses no real threat to their legalistic enterprise ${ }^{140} \mathrm{He}$ stresses again and again that he is making careful, lawyerly arguments to justify his position. ${ }^{141}$ Unfortunately, unconventional but legal amendment of the Constitution through Ackerman's five stages cannot be admitted to the canon without threatening the legalistic quality of the canon as a whole. ${ }^{142}$ Ackerman's theory blurs the law-politics distinction in a way that mainstream lawyers and scholars cannot tolerate. ${ }^{143}$

We are still left with Ackerman's instances of unconventional change: the Founding, Reconstruction, and the New Deal. How are we to understand the constitutional situation that prevailed during such periods? Ackerman's account of these three crises ignores the role of constitutional politics conceived as a structural politics of fundamental values, not as an alternative means of amendment or legal change. Each crisis produced a dynamic political situation in which departures from normal legal practice became not only thinkable, but also absolutely necessary. This dynamic sort of politics, present in some degree in every American constitutional crisis, rapidly left behind any legalistic efforts to capture and tame it.

In the case of the Founding, Ackerman's own evidence demonstrates this quite clearly. Ackerman's account does not show legalistic AntiFederalists clashing over the legality of the proposed Constitution with equally legalistic Federalists. To be sure, some opponents of the Constitution cared about legalistic arguments and some Federalists did as well. But arguments about legality did not dominate the debate. If they had, it is likely that the Constitution would not have made it past the Confederation Congress. ${ }^{144}$ Ackerman's evidence shows that most

139. I realize that Ackerman argues that Article $V$ does not offer much certainty. See id. at 69-95. I am merely pointing out here that his arguments are not likely to be persuasive because they threaten larger concerns shared by most lawyers, judges, and scholars.

140. See, e.g., 2 id. at $91-95$.

141. See 2 id. at $17,66,70,93-95$.

142. On the idea of the canon, see J.M. Balkin \& Sanford Levinson, The Canons of Constitutional Law, 111 HARV. L. REV. 963 (1998).

143. This is why I am not attracted to the idea of understanding change outside Article V by unpacking the meaning of "amendment." See Sanford Levinson, How Many Times Has the United States Constitution Been Amended?, in RESPONDING TO IMPERFECTION, supra note 1, at 13. This enterprise makes two assumptions I see no reason to make: that change outside Article $V$ must necessarily be legalistic in order to be constitutional, and that constitutional change is a matter of offering new legal interpretations of the Constitution. These assumptions may be true, but they may not. We should not assume that they are true before embarking on an investigation of constitutional change.

144. The Philadelphia Convention transmitted the proposed Constitution to the Confederation Congress after it was adopted by the Convention. See DAVID E. KYVIG, ExPLICIT AND AUTHENTIC ACTS: AMENDING THE U.S. CONSTTTUTION, 1776-1995, at 63-65 (1996). 
Federalists turned aside legalistic arguments with an appeal to the practical realities that faced the struggling republic. He remarks that in the Philadelphia Convention, "[w]ith the exception of Madison, the nationalists were strikingly unconcerned with legal technicalities." ${ }^{145}$ Edmund Randolph made a characteristic statement, saying that he "was not scrupulous on the point of power. When the salvation of the Republic was at stake, it would be treason to our trust, not to propose what we found necessary." ${ }^{146}$ In other words, the political crisis made questions of legality beside the point. Americans were at least willing to entertain the idea of abandoning the Articles of Confederation for an entirely new scheme of government with new rules of adoption and amendment.

In the case of the Civil War and Reconstruction, Ackerman rules out looking for similar evidence of the role of practical considerations by defining the alternatives to his theory in terms of a choice between Article V literalism and the "grasp of war" theory, saying that "the entire point of this book is to reject this dichotomy between legalistic perfection and lawless force." ${ }^{147}$ But these are not the only options presented by the historical record. A more generous reading of the events surrounding the Civil War and Reconstruction supports the idea that these crises created a dynamic political/constitutional situation in which measures like the forced acceptance of amendments became thinkable, necessary, and legitimate. ${ }^{148}$

To support his legalistic reading of the war, Ackerman endorses Lincoln's theory of the indissoluble Union, which held that since secession was illegal, the southern states were still in the Union. ${ }^{149}$ This creates the dilemma Ackerman uses to undermine the Article V literalists. ${ }^{150}$ Since the southern states never left the Union, their free assent was required to ratify the Thirteenth and Fourteenth Amendments. When this assent was not forthcoming, congressional Republicans departed from Article V and forced ratification through a nationalistic process that was a legally valid instance of higher lawmaking. ${ }^{151}$

This account ignores certain political realities and, more important, misses entirely the profound moral and political significance of the Civil

145. 2 ACKERMAN, supra note 1, at 50 (footnote omitted). In the case of Madison, Ackerman notes that since other Convention delegates did not encourage his concern with the legality of their proceedings, "it is not surprising that Madison abandoned his legalisms when defending the Convention's triggering decision in public." $2 \mathrm{id}$. at 430 n.63.

146. 1 THE RECORDS OF THE FEDERAL CONVENTION OF 1787, at 255 (Max Farrand ed., 1937), quoted in id. at 50. See also the discussion in RAKOVE, supra note 64, at 102-30.

147. 2 ACKERMAN, supra note 1 , at 116.

148. My argument here largely accords with that of Les Benedict. See Michael Les Benedict, Constitutional History and Constitutional Theory: Bruce Ackerman on Reconstruction and the Transformation of the American Constitution, 108 YALE L.J. 2028-29 (1999).

149. See 2 ACKERMAN, supra note 1, at 113-14.

150. See 2 id. at $99-113$.

151. See 2 id. at 120-252. 
War. With regard to Lincoln's theory, for example, historian James McPherson notes that "[i]n a practical sense, however, the Confederate states were unquestionably out of the Union." ${ }^{152}$ The southern states had seceded using all the legal formalities at their command. ${ }^{153}$ Lincoln may have hoped that they were still in the Union in spirit, but in the meantime he was fighting the bloodiest war in American history to force them to return. Further, Lincoln's understanding of the constitutional and political aspects of the War changed over time. He expressed his sense of the realities of the situation by telling an Interior Department official that when the Emancipation Proclamation took effect on January 1,1863, "the character of the war will be changed. It will be one of subjugation.... The [old] South is to be destroyed and replaced by new propositions and ideas." 154

To Ackerman, the kind of view I am advocating implies that "the Civil War amendments emerge from the guns of the Union Army," 155 instead of a legal and constitutionally legitimate process. Here, Ackerman overreaches and misses the point. From a northern perspective, the Civil War was just, moral, legal, and democratic - in short, the War was politically legitimate. Despite troubling violations of civil liberties, it was not conducted by a military overlord but by a democratically and constitutionally elected government. Indeed, a free and fair presidential election was held in 1864 while the War was going on. This means that the War had the potential to settle far more than the illegality of secession. ${ }^{156}$ The grim progress of the War created a political situation in which it was legitimate to force the ratification of constitutional amendments in order to secure the revolution it brought to the South and the nation as a whole. The War had this power not because of the guns of the Union Army but because of the sacrifices the Army had made and who the Army was-the legitimate instrument of a democratic government.

Like Ackerman and unlike most constitutional scholars, I do not want to ignore the unique circumstances surrounding the ratification of the Thirteenth and Fourteenth Amendments. ${ }^{157}$ On the other hand, I see no

152. JAMES M. MCPHERSON, ORDEAL BY FIRE: THE CIVIL WAR AND RECONSTRUCTION 404 (2d ed. 1992).

153. See id. at 131-36.

154. Quoted in JAMES M. MCPHERSON, BATtLE CRY OF FREEDOM: THE CIVIL WAR ERA 558 (1988) (footnote omitted).

155. 2 ACKERMAN, supra note 1 , at 115.

156. Compare Ackerman: "All that the victory of the Union army established was the failure of secession. It did not establish the terms for reunion, and certainly did not establish that most Americans supported a move beyond the Thirteenth Amendment." 2 id. at 22. I disagree with this judgment for the reasons stated in the text.

157. Indeed, I made the argument that the forced acceptance of these amendments was an important clue to the nature of American constitutionalism in Stephen M. Griffin, Constitutionalism in the United States: From Theory to Politics, 10 OXFORD J. LEGAL STUD. 200, 209 (1990). 
reason to adopt Ackerman's five-stage theory of functional amendment to explain the legitimacy of the amendments unless there is clear historical evidence in its favor. Here is where Ackerman's theory encounters insuperable problems. Did participants in the debates over the Founding, Reconstruction, and the New Deal self-consciously agree that they were creating a multi-stage sequence of higher lawmaking that supplemented the procedure provided by Article V? This is what is required for Ackerman to meet conventional understandings of what is necessary to create law. Without self-conscious understanding, Ackerman still has an historical narrative that greatly deepens our understanding of how constitutional change has occurred through essentially political means. But he does not have evidence of a legal process. If Ackerman had such evidence, he would be able to show New Dealers, for example, saying something like the following: "Thank heavens for the precedent of Reconstruction. We don't have to go to the states to get amendments approved! We can do it through the nationalistic means created by the 1866 Republican Congress."

Of course, nothing like this was ever said. If it had been, we would have heard about it before Ackerman began his research. The legitimacy of the Thirteenth and Fourteenth Amendments can be explained as the outcome of a complex process that is best understood as an instance of structural politics-a sort of politics that is uniquely focused on fundamental constitutional values and how best to realize them. The circumstances surrounding their ratification were an excellent example of this kind of politics in action.

Once shorn of the five-stage sequence and the notion of functionally equivalent amendments, there is much that is important remaining in Ackerman's account of Reconstruction. It is an invaluable account of the unique constitutional/political circumstances in which Americans found themselves at the end of the Civil War. Ackerman shows how Congress struggled to formulate new constitutional ideas to deal with a highly unusual political situation. But he does not show that the Congress selfconsciously adopted a new method of amendment that supplemented the procedure found in Article V. In trying to make this case, Ackerman is reaching for something that the legalism he admires will not let him have. Giving a proper constitutional account of the Founding, Reconstruction, and the New Deal means accepting the necessity of moving back and forth across the shifting border between law and politics without embracing either. 


\section{B. Historicism and Constitutional Interpretation}

We are in the midst of a recognition by constitutional theorists that "we are all originalists, we are all non-originalists." ${ }^{158}$ This observation is accurate to the extent that scholars of many different persuasions have been driven to acknowledge that legal and constitutional interpretation inevitably draws on the past to give light to the present. ${ }^{159}$ Unfortunately, this has also led legal scholars to suppose that in using the past to interpret the Constitution, they have the same perspective as historians. ${ }^{160}$ This is not the case.

Constitutional interpretation involves creating narratives of continuity. Restorationism is a good example, one that relies on language carefully selected from foundational precedents while ignoring their political and institutional context. It thus creates a false continuity between the Jacksonian era and the New Deal. What is important to see, however, is that any effort to validate the New Deal by conventional means of legalistic constitutional interpretation will have to do the same thing. Whether such interpretations are based on more robust evidence of original intent or on an approach that emphasizes the abstract character of the constitutional text, the result will be a narrative of continuity that disables us from a more realistic appreciation of the discontinuities of American constitutional history. In many ways, an historicist understanding of constitutional development is at odds with the interpretive perspective.

While historicism means different things to different historians, what is common to the historicist perspective emerges sharply when historians encounter the use of history in legal scholarship. ${ }^{161}$ As Robert Gordon has observed, the use of history in legal argument is inevitable. ${ }^{162}$ For lawyers, the past is a source of authority, tradition, identity, and inspiration. But when constitutional lawyers engage in determined attempts to reconstruct the past, they run into a paradox. The lawyer "is likely to find herself in an

158. Larry D. Kramer, Madison's Audience, 112 HARV. L. REV. 611, 677 (1999).

159. See, e.g., Michael C. Dorf, Integrating Normative and Descriptive Constitutional Theory: The Case of Original Meaning, 85 GEO. L.J. 1765 (1997).

160. For a recent illustration of this view, see Saikrishna B. Prakash, Unoriginalism's Law Without Meaning, 15 CONST. COMMENTARY 529, 535 (1998) ("[H]istory and originalism either sink or swim together....") (reviewing RAKOVE, supra note 64). As I argue, originalism and historicism have little to do with each other. Prakash's failure to understand this results in a review that completely ignores Rakove's important insights into the Founding period. Rakove's book won the Pulitzer prize for history, but one would never know why from this review.

161. For recent general works that provide insight on the craft of history and the historicist perspective, see JoYCE APPLEBY ET AL., Telling THE TRUTH ABOUT History (1994); PAUL A. COHEN, HISTORY IN THREE KEYS: THE BOXERS AS EVENT, EXPERIENCE, AND MYTH (1997); PETER Novick, That NOBle DREAM: ObJeCTIVITY AND THE AMERICAN Historical PROFESSION (1989).

162. See Gordon, The Past as Authority, supra note 18, at 340. 
alien and unrecapturable social and conceptual world." ${ }^{163}$ The more the past is revealed, the more its usefulness in addressing the problems of the present recedes.

The paradox is intensified by the fact that constitutional lawyers and scholars are interested usually in just two periods of American history: Founding and Reconstruction. ${ }^{164}$ The great concentration on these two periods means that the dynamic qualities of history are lost as these periods are studied as if they were isolated islands in the American experience. After performing what are frequently immense labors studying the late eighteenth century and the mid-nineteenth century, scholars time-jump to the contemporary world to announce their findings. They do not bother to check whether their findings would be altered by studying what has happened since the Founding and Reconstruction. They have no model, similar to that offered by historical institutionalism, to understand American political development or changes in the national state over time.

In trying to avoid the paradox and ensure that their labors yield results, constitutional scholars run into a number of difficulties. The most significant are well summarized by William E. Nelson in his important work on the Fourteenth Amendment. ${ }^{165}$ First, scholars tend to ask "questions of twentieth-century significance that cannot be answered by historical inquiry." ${ }^{166}$ Questions presented by contemporary Supreme Court cases may never have even occurred to the Founding generation or the Framers of the Reconstruction amendments. Such questions are nonetheless asked and records ransacked, although there is no conceivable historical evidence that could answer them. Second, "scholars have inquired about how the Framers would have resolved issues they did consider but in fact never resolved." ${ }^{167}$ The need for answers forces scholars to contort the available evidence until it yields a particular result.

I will call this second difficulty "the missing third alternative." Scholars are driven by the need to solve issues raised by a case, and each case has only two sides. Scholars thus frame the historical issue around two polar alternatives: Either the plaintiff or defendant is right. The idea that the evidence may be missing or ambiguous so that neither is right is not considered. It is this missing third alternative that most clearly distinguishes an historicist perspective such as Nelson's from the kind of perspective prevalent in legal scholarship. As Nelson says, the proper task of historical

163. Id. at 341 .

164. Why not the New Deal? Because, of course, lawyers and scholars think they know what happened during the New Deal-it was merely a restoration of the Founding, by way of the Marshall Court.

165. See William E. Nelson, The fourteenth Amendment: From Political PRINCIPLE TO JUDICIAL DOCTRINE (1988).

166. $1 d$. at 6.

167. Id. 
scholarship is to identify "the meaning which the amendment had for its proponents, even if that meaning is not dispositive of the issues pending in the courts today." ${ }^{168}$ For him, "[t]he essence of history is the identification of continuities and discontinuities between past and present." ${ }^{169}$ If the historical evidence shows a discontinuity such that contemporary constitutional questions cannot be answered, this must not be ignored.

Michael Les Benedict usefully expands on Nelson's points. ${ }^{170}$ Benedict criticizes legal scholars for simply focusing on a particular event, rather than the continuous process of historical change. Benedict comments that "[h]istorians are particularly concerned with how institutions and ideas have changed over time: A key purpose of history is to describe how past ideas and institutions differed from those of the present. Change is to be described and explained, not judged." 171 Benedict recognizes that legal scholars may have other purposes in view. The need to interpret a constitutional provision to decide a given case does not go away simply because the evidence is ambiguous. Legal scholars thus employ special rules, often drawn from statutory construction, to sort out and filter the evidence so that meaning can be ascertained and the case decided. ${ }^{172}$

Unfortunately, particularly when courts engage in this kind of restricted history, the results are unconvincing. ${ }^{173}$ The meanings and ambiguities uncovered by historians compete with and undermine the conclusions trumpeted with such certainty by judges and legal scholars. As Eric Foner comments with respect to discussions of the history of the Fourteenth Amendment: "Too often [legal scholars] restricted themselves simply to an exegesis of selected quotations from the Congressional debates rather than examining the full historical context, without which these quotations lack real meaning." 174 Restorationism, which I debunked at the outset, is an example of an acontextual legal history that indeed has some basis in the historical evidence-Chief Justice Marshall did write those broadly worded opinions, didn't he? Any use of Marshall's opinions to validate the New Deal, however, involves the claim that Marshall meant to endorse the general sort of governmental power necessary to enact New Deal legislation. As the historical evidence shows, this was not the case. To

168. Id.

169. Id. at 10.

170. See Michael Les Benedict, Book Review, 10 L. \& HIST. REv. 377 (1992).

171. Id. at 379.

172. See id. at 380 .

173. See the original critique of "law-office" history by Alfred H. Kelly, Clio and the Court: An Illicit Love Affair, 1965 SUP. CT. REV. 119. In recent years, Kelly's argument has been updated and confirmed by other scholars. See, e.g., Neil M. Richards, Clio and the Court: A Reassessment of the Supreme Court's Uses of History, 13 J.L. \& POL. 809 (1997); William M. Wiecek, Clio as Hostage: The United States Supreme Court and the Uses of History, 24 CAL. W. L. REV. 227 (1988).

174. Eric Foner, The Supreme Court's Legal History, 23 RUTGERS L.J. 243, $243-44$ (1992). 
invoke Marshall's authority in the context of the New Deal is anachronistic. There is no relevant similarity between the two periods that would allow us to even begin exploring what Marshall would have thought about the New Deal.

The example of restorationism shows that while we can use legal rules to generate historical certainties, we cannot somehow wall out the evidence produced by historicist inquiry. Or at least, as I shall argue below, we should not ignore it as scholars. The Supreme Court has been quite inventive in this respect. In Planned Parenthood v. Casey, ${ }^{175}$ the Court's most explicit consideration of the questions raised by constitutional change, Justices O'Connor, Kennedy, and Souter argued that the Court's most famous changes in view were the result of changes in the facts. ${ }^{176}$ With respect to the demise of Lochner, the key factor was that "the interpretation of contractual freedom... rested on fundamentally false factual assumptions about the capacity of a relatively unregulated market to satisfy minimal levels of human welfare." ${ }^{177}$ The other shift was the transition from Plessy v. Ferguson ${ }^{178}$ to Brown v. Board of Education. ${ }^{179}$ Here the decisive factor was that "[s]ociety's understanding of the facts upon which a constitutional ruling was sought in 1954 was thus fundamentally different from the basis claimed for the decision in 1896." 180 Both changes were justified because "each rested on facts, or an understanding of facts, changed from those which furnished the claimed justifications for the earlier constitutional resolutions." 181

The motto of the Ursuline Academy, a venerable Catholic school for young women in New Orleans, is: "Times change, values do not." Apparently, this could serve for the Court. What I will call the "Casey fallacy" is the assumption that significant constitutional changes are solely a matter of changes in facts, rather than changes in values. ${ }^{182}$ Any reputable

175. 505 U.S. 833 (1992).

176. See id. at $861-64$.

177. Id. at $861-62$.

178. 163 U.S. 537 (1896).

179. 347 U.S. 483 (1954).

180. Casey, 505 U.S. at 863.

181. Id.

182. This fallacy is one of the key problems with Lessig's theory of translation. Like Ackerman and myself, Lessig rejects restorationism as a way to understand how constitutional change occurred legitimately in the New Deal. See Lessig, Understanding, supra note 1, at 44648. Lessig contends, however, that changes in the facts can justify the New Deal decisions. He quotes Chief Justice Hughes's opinion in West Coast Hotel v. Parrish, 300 U.S. 379 (1937), to show the role of changed facts. Hughes refers to "recent economic experience" which has revealed the "exploitation" of workers who occupy an "unequal" economic position and are "relatively defenceless." Id. at 399 (quoted in Lessig, Understanding, supra note 1, at 460). He takes judicial notice of the Depression and says there is no need to provide a subsidy to "unconscionable employers." Id. The state has the right "to correct the abuse which springs from their selfish disregard of the public interest." Id. 
history of these doctrinal shifts makes it very plain why the Casey Court was mistaken. ${ }^{183}$ With respect to Lochner, the Court gives the game away by using value-laden terms such as "contractual freedom" and "human welfare." There is a sense in which the Lochner majority was surely aware that many Americans at the turn of the century were not well off. This did not bother the majority because they presumably believed that the operation of constitutional doctrines such as substantive due process were part of a total system that ultimately worked to the benefit of all Americans. This is, of course, a value judgment that the Justices appointed by FDR did not share. They believed that state legislatures had a role in acting directly to increase human welfare through detailed laws regulating conditions of labor.

The change in values is, if anything, even more apparent in Plessy. As Michael Klarman has recently reminded us, the turn of the nineteenth century was a time when the supremacy of the white race was asserted confidently. ${ }^{184}$ To the Court, state-imposed segregation was a reasonable means of ensuring that members of two different races would not be forced into a situation of social equality before they were ready. ${ }^{185}$ That these laws were part of a system designed to keep blacks in their place was simply ignored. The decision the Court made in Brown not to ignore this reality reflected a change in values. In the restrained phrasing of Morton Horwitz,

These are facts? At the very least Hughes's argument turns on a mixture of facts and values. Almost all the terms Hughes uses are unambiguously value-laden. Why is it so important for Lessig to avoid the idea that historical change involves changes in values? Lessig wants to show that the Court can maintain fidelity with the past even in areas where constitutional law has undergone drastic shifts without the benefit of Article $V$ amendments. As he sees it, the key to maintaining fidelity is to make sure that the Framers' values are brought up to date through a process of translation that compares their background context with our own. The problem here is that the Framers' values, even the general ones that they embodied in the Constitution, were part of a larger historical worldview that no longer exists. See William W. Fisher III, Texts and Contexts: The Application to American Legal History of the Methodologies of Intellectual History, 49 STAN. L. REV. 1065, 1106-07 (1997) (arguing that when shifts in "ideology" or "world view" are involved, "then equivalence of the sort Lessig celebrates seems chimerical").

As I showed in Part I, the context surrounding Marshall's interpretation of the Commerce Clause included a commitment to an extremely limited federal role in regulating the economy. Given this value commitment, there is no possibility of maintaining true fidelity with the Marshall Court. If we include all of Marshall's values in our translation effort, we will not be able to justify the New Deal. On the other hand, if we selectively edit the past to remove those values that are antithetical to the modern regulatory state, we have given the game away. Deciding on our own which past values to keep and which to discard does not maintain "fidelity" with those values.

183. See the sources cited supra note 100 on the history of the Due Process Clause and Commerce Clause between the Civil War and the New Deal.

184. See Michael J. Klarman, Race and the Court in the Progressive Era, 51 VAND. L. REV. 881, 886-95 (1998).

185. See Plessy, 163 U.S. 537, 551-52 (1896). 
the Casey Court "did not explore the dynamic nature of social or legal consciousness." 186 Times change, and facts and values change with them.

In recent years, some legal scholars have begun defending the idea of a "usable past" and suggesting that this justifies a lawyerly approach to history. ${ }^{187}$ Cass Sunstein argues that although history does impose constraints on the constitutional lawyer, the lawyer's role in looking to history differs from that of the historian. ${ }^{188}$ The lawyer's project is "to make the best constructive sense out of historical events associated with the Constitution." "189 While the historian tries to "reimagine the past... the constitutional lawyer is trying to contribute to the legal culture's repertoire of arguments and political/legal narratives that place a (stylized) past and present into a trajectory leading to a desired future." 190

I do not object to this view to the extent that it is a program for the constitutional lawyer rather than the constitutional scholar. It is evident from Sunstein's remarks, however, that he thinks this approach to history is also suitable for scholars. He distinguishes the advocate who "begins with a preestablished conclusion" ${ }^{191}$ from the constitutional lawyer who seeks the truth. ${ }^{192}$ But real-world experience with "law-office" history ${ }^{193}$ has shown that Supreme Court Justices and constitutional lawyers inevitably tend to act as advocates rather than lawyers, to use Sunstein's terms. I would distinguish between Justices and lawyers as advocates interested in persuasion on the one hand, and scholars on the other.

From a scholarly point of view, Sunstein makes no allowance for anachronism-the asking of questions of the past that the past cannot answer. With respect to the "missing third alternative," presumably he would say that we should not contort the evidence when it does exist, but is too ambiguous. Unfortunately, this would eliminate a wide swath of the appeals to history that are standard in constitutional lawyering. The most important difficulty is that Sunstein does not come to grips with the reality that all of American history is potentially relevant to his project. ${ }^{194}$ The events "associated with the Constitution" almost always turn out to be the Founding and Reconstruction, not the rest of American history. It is what

186. Morton J. Horwitz, The Supreme court, 1992 Term-Foreword: The Constitution of Change: Legal Fundamentality Without Fundamentalism, 107 HARV. L. REV. 32, 92 (1993); see also id. at 71-92 (criticizing Casey).

187. See, e.g., Cass R. Sunstein, The Idea of a Useable Past, 95 COLUM. L. REV. 601 (1995).

188. See id. at 602.

189. Id. (emphasis in original). Sunstein's statement illustrates what I mean when I say that constitutional lawyers and scholars use history to produce narratives of continuity.

190. Id. at 605 .

191. Id. at 603 .

192. Id.

193. See sources cited supra note 173.

194. See Stephen M. Griffin, Legal Liberalism at Yale, 14 CONST. COMMENTARY 535, 54649 (1997) (reviewing LAURA KALMAN, THE STRANGE CAREER OF LEGAL LIBERALISM (1996)) 
has happened since the Founding and Reconstruction that will largely determine whether any contested constitutional practice makes sense today. Recall that the point of this procedure is to cast light on the present and point the way to the future. Given my analysis of constitutional change, there is no way to do this without taking account of all events in American history that bear to a significant degree on the development of the state.

In addition, Sunstein does not appreciate the extent to which the historicist perspective competes with the goal-directed approach he prefers. He defends the practice of giving "special weight to the convictions of those who ratified constitutional provisions," 195 but does not take account of Foner's argument that understanding what the Framers and ratifiers meant depends on a larger historical inquiry that can easily undermine the certain conclusions judges and lawyers wish to reach. Finally, Sunstein underestimates the role historians can play in criticizing and destabilizing the arguments lawyers and judges make. He notes that constructing a usable past necessarily means bypassing aspects of constitutional history that are not useful for present purposes. ${ }^{196}$ Slavery and the narrow conception of free speech prevalent in the Founding era are two examples. ${ }^{197}$

This is a serious error that illustrates very well the difference I wish to draw between the approach of the Sunstein-inspired lawyer, judge, and law professor on the one hand, and the historicist scholar on the other. This also demonstrates how a preference for narratives of continuity can lead scholars to ignore the discontinuities in American history. ${ }^{198}$ Without an historicist perspective, we cannot meaningfully confront the view of Justice Thurgood Marshall that the Constitution devised by the Founding generation "was defective from the start, requiring several amendments, a civil war, and momentous social transformation to attain the [present] system of constitutional government." ${ }^{199}$ The Dworkinian project of looking to the best constructive use of the past encourages the bad habit that lawyers, judges, and law professors already have of ignoring the darker side of American constitutionalism. Tragedies and discontinuities such as slavery, the Civil War, Reconstruction, and the New Deal are part of the American constitutional story and must be confronted honestly if we are to understand the contemporary constitutional world.

195. Sunstein, supra note 187 , at 604 .

196. See id. at 605 .

197. See id.

198. For a similar criticism of Sunstein, see Fisher, supra note 182, at 1108.

199. Thurgood Marshall, Reflections on the Bicentennial of the United States Constitution, 101 HARV. L. REV. 1, 2 (1987). For relevant commentary, see Raymond T. Diamond, No Call to Glory: Thurgood Marshall's Thesis on the Intent of a Pro-Slavery Constitution, 42 VAND. L. REV. 93 (1989). 
As I indicated above, I accept the idea, reflected in the recent work of Sunstein and others, that lawyers and historians have different tasks. ${ }^{200}$ As Laura Kalman has reminded us, "historians still favor context, change, and explanation.... [while lawyers] value text, continuity, and prescription." ${ }^{201}$ While the Court clearly recognizes the validity of what Philip Bobbitt calls "historical argument" 202 as a method of constitutional interpretation, it is history done the Court's way, that is, "law-office" history. To win cases, lawyers must argue in a way that conforms with the standards of this mode of argument. The Court's influence, however, extends far beyond the lawyers who appear before it. Indeed, its antihistorical orientation pervades American constitutionalism.

Studying the Court's pronouncements on history and building historical arguments that conform to the Court's standards in order to resolve current and future constitutional controversies is clearly an appropriate and valuable task for law professors. What is problematic is the idea that in so doing, they are conforming with the requirements of sound scholarship. If the Court believes in restorationism, lawyers and law professors will tend to go along, if only to ensure that their arguments have some influence with the justices. By contrast, scholarship involves a commitment to seeking the truth, wherever it may lead. ${ }^{203}$ A corollary scholarly virtue is critical distance, which means being willing to question your own assumptions as well as commonly held beliefs. This implies an attitude of skepticism and a willingness to search for contrary evidence. ${ }^{204}$ One might say that scholars seek an ideal of discussion and debate in which the only standard is the force of the better argument. ${ }^{205}$

200. In drawing the distinctions in this Section, I do not wish to be misunderstood. I am not arguing that historians engage in description without the need to assume a normative point of view. The difference between historians and lawyers is not that the former are interested solely in description or explanation while the latter are interested solely in prescription. While historians do focus on description and explanation, the crucial difference is that they bring a much broader normative perspective to bear on historical evidence. To oversimplify, lawyers are interested in resolving cases by building narratives of continuity. Historians are not so limited and often focus on discontinuities between the present and the past.

201. KALMAN, supra note 194 , at 180 (footnote omitted).

202. See PHILIP BOBBITT, CONSTITUTIONAL FATE 9-24 (1982).

203. See generally Stephen M. Griffin, What Is Constitutional Theory? The Newer Theory and the Decline of the Learned Tradition, 62 S. CAL. L. REV. 493 (1989) (outlining a new paradigm of rigorous constitutional theory).

204. See Keith E. Whittington, Constitutional Theory as Political Science 3-4 (unpublished manuscript on file with The Yale Law Journal).

205. See JuRgen Habermas, Legrtimation CRISIS 107-08 (1975). See also the views of Rogers Smith, who recently provided a statement of his own ideal of scholarship with respect to his home discipline of political science:

I have come to favor a Socratic view of our professional mission. I think we are at our best when we are intellectual gadflies, rigorously questioning and testing accepted political truths, exploring ignored possibilities, courting unpopularity by offering suggestions that markets are not likely to reward and that people in power are not likely to approve. 
So while I agree that the paths of the lawyer and historian are different and in some sense equally valid, what I do not accept is the idea that the paths of the lawyer and the constitutional scholar are the same. The issue for constitutional law professors is which perspective they wish to adopt. They can certainly write as lawyers or as scholars, but not both at the same time. Constitutional law professors can do valuable work before the Court and write significant law review articles from a lawyerly perspective. But this is not constitutional scholarship. Scholarship involves a commitment to questioning, if warranted, the necessary fictions of constitutional law. If arguments are available that undermine a strictly legalist perspective, then those arguments cannot be avoided without compromising intellectual honesty. The reality that the Court adheres to mistaken historical views such as restorationism or the idea that only facts change, not principles and values, provides no reason why scholars must accept them.

In specifying a path for a transformed constitutional theory then, I hope I have made it clear that this is constitutional theory understood as scholarship, not as an aid to constitutional lawyering. Constitutional theory should assume an historicist perspective and take seriously the problems posed by constitutional change. As I hope to show, these commitments would have a dramatic impact on both the scope and content of American constitutional theory.

\section{Constitutional Theory Transformed}

An historicist perspective allows us to develop what might be called a contextualized constitutional theory. ${ }^{206}$ When a clause of the Constitution, Supreme Court precedent, constitutional practice or institution is at issue, it must first be set in historical context before a meaningful normative argument can take place. The tasks of description and explanation are prior to the task of evaluation. As I have argued, the most appropriate general context for evaluating American constitutionalism is that suggested by historical institutionalism. We begin with the concept of the state and the

Smith, Still Blowing in the Wind, supra note 7, at 278.

206. Recently, Judge Richard Posner defined constitutional theory as "the effort to develop a generally accepted theory to guide the interpretation of the Constitution of the United States." Richard A. Posner, Against Constitutional Theory, 73 N.Y.U. L. REV. 1, 1 (1998). I have explained elsewhere why this common definition is far too narrow. See GRIFFIN, supra note 1, at 3-4. We do not gain much by general definitions, but properly understood, constitutional theory concerns any theoretical issue raised by the distinctive practice of American constitutionalism. See $i d$. at 4. More helpfully, Judge Posner calls for a greater degree of attention to the empirical issues pertaining to constitutionalism. See Posner, supra, at 11-12. As I argued 10 years ago, these issues are certainly relevant to constitutional theory, and it is unfortunate that constitutional scholars have neglected them. See Griffin, supra note 203. But Posner does not use this gesture toward empiricism as an opportunity to rethink the nature of constitutional theory. The historicist perspective I have described in this Essay offers us a better chance to do this. 
problem of the relation of the Constitution to American political development. We then work out a theory of constitutional change to explain this relation and lay the groundwork for normative inquiry.

This means that the theory of constitutional change is prior to the task of constitutional interpretation. ${ }^{207}$ All theories of constitutional interpretation, not just originalism, depend on an explicit or implicit historical baseline to get their arguments off the ground. The only way to justify what baseline to start from, however, is through an historicist theory of constitutional change. I have sought to illustrate this point here by critiquing restorationism. The Justices who employed restorationism, such as Jackson and Douglas, were not originalists as that term is usually employed. Their justification for the New Deal necessarily turned, however, on an appeal to history because that was the only way to preserve the continuity of American constitutionalism.

The general form of the argument against restorationism allows us to do something that is fairly rare and very underrated in contemporary constitutional theory-debunking a normative argument by critiquing its descriptive-explanatory basis. Here, restorationism is the normative argument. It asserts the legitimacy of something that happened in the 1930s and is, in some sense, still with us by referring us to authoritative pronouncements made in the distant past. When we examine the historical context of those statements, however, we discover that it is not plausible to maintain that they were endorsing practices that resemble those of our own time. Further, when we take care to specify the institutional context in which those statements were made, we find that practices resembling those of our own time simply did not exist. It becomes apparent that asking the past to validate episodes such as the New Deal is to ask questions of history that history cannot answer. ${ }^{208}$ This debunks the normative claim at the heart of restorationism by taking away its basis in history. Without historical plausibility, restorationism becomes a purely doctrinal claim that statements in the past resemble statements we would like to use in the present to endorse certain contested practices.

Debunking restorationism raises the question of how many other normative arguments commonly made in constitutional law and theory could stand up to a similar descriptive-explanatory examination. Arguments made by originalists may appear to be obvious candidates for possible

207. For an example of the unconventional view that the theory of constitutional interpretation comes first, see James E. Fleming, We the Unconventional American People, $65 \mathrm{U}$. CHI. L. REV. 1513 (1998) (reviewing 2 ACKERMAN, supra note 1). Fleming criticizes Ackerman for not offering a theory of constitutional interpretation. See 2 id. at 1522, 1537. What Fleming does not see is that the task of constructing a theory of constitutional change necessarily comes first. It is only through a better understanding of constitutional change that unrealistic narratives of continuity can be avoided.

208. See H. Jefferson Powell, Rules for Originalists, 73 VA. L. REV. 659, 662-66 (1987). 
debunking, but I am interested in the far more widespread and casual use of references to past decisions, whether made by the Founding generation or the Marshall Court. For example, it is common in both administrative law and federal courts jurisprudence to take some Founding-era pronouncement as given without asking whether current practices are so different from the practices of the early republic as to make the Founding-era statement irrelevant. ${ }^{209}$ To ask this question in a meaningful way, of course, we must have a baseline from which to judge Founding-era institutions against our own. This is where historical institutionalism makes a useful contribution. Instead of relying on uselessly general terms to describe the early American state, we focus with more precision on the structure of government institutions and whether they were able to wield authority effectively.

I stress that the point of doing this is not primarily to assist the Supreme Court or constitutional lawyers in their important tasks. I do not assume or expect that the Court will be able to adopt a contextual view of its role in history. That is why I emphasize the differences between lawyering and constitutional theory as scholarship. This point extends to the development of contextual theories of judicial review and constitutional interpretation. These theories should be developed in accordance with scholarly values, not the values of lawyering or judging.

The difference that an historicist approach can make to the traditional questions of constitutional theory can be dramatic. With respect to theories of judicial review, Judge Posner provides an example by referring to the contention that judicial review is undemocratic. ${ }^{210} \mathrm{He}$ argues that this "begs the question" because "[t]he Court is part of the Constitution, which in its inception was rich in undemocratic features." 211 This is, of course, a common argument and rejoinder. To assess it in an appropriate scholarly way, however, we would have to explore what has happened since the adoption of the Constitution. We would have to do this not simply with reference to changes in the text of the Constitution (to which Posner refers), ${ }^{212}$ but to the development of democracy in the United States as an historical phenomenon and its relation to the evolution of state institutions. For example, Morton Horwitz has argued that the growing prestige of democracy in the twentieth century had a substantial impact on the Supreme Court even as the text of the Constitution stood still. ${ }^{213}$ This means

209. See, e.g., Akhil Reed Amar, A Neo-Federalist View of Article III: Separating the Two Tiers of Federal Jurisdiction, 65 B.U. L. REV. 205, 212 (1985) (finding no constitutional mandate to create any lower federal courts); Cass R. Sunstein, Constitutionalism After the New Deal, 101 HARV. L. REV. 421, 467 (1987) (criticizing Chevron v. NRDC on the ground that it contradicts Marbury v. Madison).

210. See Posner, supra note 206 , at 6.

211. Id.

212. See id.

213. See Horwitz, supra note 186 , at 57-65. 
that it is Posner who is begging the question. The political or nonlegalized aspects of the Constitution developed in a more democratic direction in the twentieth century and thus influenced the Court. It is anachronistic to refer to the 1787 Constitution as settling the question of the relation between judicial review and democracy because that governing order is no longer with us. ${ }^{214}$

Similarly, an historicist perspective makes an obvious difference to the development of theories of constitutional interpretation by avoiding debates that are anachronistic. Ackerman makes this apparent when he argues that Lochner should be viewed in the context of its own time. ${ }^{215}$ The context that Ackerman provides is his own and certainly not all historians would agree with it. But the general point is clear enough. It is pointless to ask, for example, whether there is a difference between Lochner and Roe $v$. Wade. ${ }^{216}$ This does not mean we should bring back the Lochner era, only that we should recognize that contemporary constitutional law and Lochner-era jurisprudence are both products of the unresolved political and legal conflicts of their time.

An historicist perspective does not favor any of the contending theories of interpretation, whether originalist or nonoriginalist. Whether these theories are best understood as modes of constitutional argument grounded in different sources of law ${ }^{217}$ or as interpretive proposals backed by more general theories of law and moral-political philosophy, ${ }^{218}$ they are all equally ahistorical. This is not a criticism, it is simply a fact of life. To be credible to an audience that is assumed to consist of federal judges, the theories have to work within the Court's parameters. As I have argued, those parameters do not include an historicist perspective. This means that contextual constitutional theory and theories of interpretation do not share the same goals. The goal of contextual constitutional theory is to understand where American constitutionalism has been, where it is now, and where it is going. The resolution of specific cases is a task for lawyers engaged in the exigencies of practice, not theorists engaged in a scholarly inquiry.

The issues that should concern constitutional theorists have to do with the relation of the Constitution-understood as the fundamental institutions, rules, and practices that structure politics-to the contemporary challenges facing the United States. In other words, constitutional theory should be placed in contact with the historical circumstances of American politics.

214. For how the argument regarding judicial review should proceed given this historical approach, see GRIFFIN, supra note 1, at 63-66.

215. See 1 ACKERMAN, supra note 1, at 64-66.

216. 410 U.S. 113 (1973).

217. For discussion of this model, which I have called the pluralist theory of constitutional interpretation, see GRIFIN, supra note 1 , at 143-52.

218. See, e.g., DWORKIN, supra note 128; RONALD DWORKIN, LAW's EMPIRE (1986). 
This certainly does not exclude discussion of the Supreme Court and fundamental rights. In a contextualized constitutional theory, however, such traditional discussions would take place against the backdrop of the efforts of all branches and levels of government to deal with the politics of rights and the consequences of that politics. Any issue of rights or interpretation of a particular phrase of the Constitution would have to be set in a broad historical and institutional context before progress could be made in understanding or debating it. Any normative proposal regarding a constitutional right would have to take account of this broad backdrop before it could be regarded as plausible.

Besides Ackerman, Louis Michael Seidman and Mark Tushnet, ${ }^{219}$ Michael Klarman, ${ }^{220}$ Sanford Levinson, ${ }^{221}$ Martin Flaherty, ${ }^{222}$ and Barry Friedman ${ }^{223}$ have all adopted historicist perspectives in their recent works. In discussing the debate over the Court's ability to protect minority rights, for example, Klarman calls for constitutional historians (by my way of thinking, constitutional scholars in general) to "situat[e] constitutional disputes within their complex historical contexts ... [and to] identify the sorts of background forces-political, social, economic, cultural, ideological-that render possible dramatic shifts in constitutional doctrine." 224 The goal here is to understand "the parameters within which judicial review actually operates." ${ }^{225}$ Here, Klarman provides an excellent example of precisely the sort of inquiry constitutional scholars should undertake and a model for how they should proceed. ${ }^{226}$

219. See SEDMAN \& TUSHNET, supra note 80.

220. See Michael J. Klarman, Rethinking the Civil Rights and Civil Liberties Revolutions, 82 VA. L. REV. 1 (1996) [hereinafter Klarman, Rethinking]; see also Michael J. Klarman, How Brown Changed Race Relations: The Backlash Thesis, 81 J. AM. HIST. 81 (1994).

221. See, e.g., RESPONDING TO IMPERFECTION, supra note 1; Sanford Levinson, The Specious Morality of the Law, HARPER'S, May 1977, at 35. Levinson's seminal article somehow anticipated both the "republican revival" of the 1980s and the future importance of the issue of constitutional change.

222. See Martin S. Flaherty, History "Lite" in Modern American Constitutionalism, 95 COLuM. L. REv. 523 (1995); Martin S. Flaherty, The Most Dangerous Branch, 105 YALE L.J. 1725 (1996).

223. See Barry Friedman, The History of the Countermajoritarian Difficulty, Part One: The Road to Judicial Supremacy, 73 N.Y.U. L. REv. 333 (1998); Barry Friedman \& Scott B. Smith, The Sedimentary Constitution, 147 U. PA. L. REV. 1 (1998).

224. Klarman, Rethinking, supra note 220, at 31-32.

225. Id. at 32 .

226. See also the instructive exchange between Klarman and Michael McConnell on the constitutionality of school segregation in the nineteenth century. From my point of view, Klarman argues as a slightly puzzled historicist against McConnell's aggressive legalist position. See Michael J. Klarman, A Response to Professor McConnell, 81 VA. L. REv. 1881 (1995); Michael W. McConnell, A Reply to Professor Klarman, 81 VA. L. REV. 1937 (1995). Klarman is responding to McConnell's earlier article, Michael W. McConnell, Originalism and the Desegregation Decisions, 81 VA. L. REV. 947 (1995). 
In political science, the scholars whose views come closest to my own (besides historical institutionalists interested in constitutional law), ${ }^{227}$ are those associated with the Committee on the Political Economy of the Good Society (PEGS). ${ }^{228}$ They refer to their work as the "new constitutionalism" because it focuses attention on "the perspective of an institutional designer." ${ }^{229}$ The point is to study the design of the political order as a whole with a view toward diagnosing problems of that order and considering whether reforms can be made. ${ }^{230}$

The PEGS viewpoint is useful also because it serves to answer a question some scholars may have about the historicist project. That is, if the purpose of constitutional theory as scholarship is not to help the Court, then what is its purpose? Of course, the tasks of description and explanation have their own claims to make, but I can imagine some scholars still wonder about the normative motivation of my methodological proposals. The example of restorationism helps answer these concerns to a certain extent. There are normative claims worth debunking, and once they are debunked we may see a way clear to a better normative view. But a view to do what?

My interest in constitutional change and an historicist perspective on American constitutionalism is motivated by the sense that the United States is in a period of unusual challenges to its governing institutions. At the same time, the concepts and vocabulary bequeathed to us by our constitutional tradition seem singularly inappropriate to address those challenges. This state of affairs calls for a constitutional theory that gives us the ability to understand how we arrived at this situation and a sure grasp of the problems and capabilities of American government. And understanding is the best way to characterize the goal of constitutional theory. The purpose of constitutional theory is not merely to describe, explain, evaluate,

227. Among recent works by historical institutionalists, the two that are most suggestive for future constitutional theory are STEPHEN SKOWRONEK, THE POLITICS PRESIDENTS MAKE: LEADERSHIP FROM JOHN ADAMS TO GEORGE BUSH (1993) and ROGERS M. SMITH, CIVIC IDEALS: CONFLICTING VISIONS OF CITIZENSHIP IN U.S. HISTORY (1997). Smith's book is particularly relevant to what I have argued here in that it shows that American constitutionalism cannot be reasonably represented as a narrative of continuity.

For other works by political scientists that are relevant to the project of a contextualized constitutional theory, see GLLMAN, supra note 100; SKOwRONEK, supra note 7; and Graber, supra note 125. See also the following recent works: MARK A. BRANDON, FREE IN THE WORLD: AMERICAN SLAVERY AND CONSTITUTIONAL FAILURE (1998); WAYNE D. MOORE, CONSTITUTIONAL RIGHTS AND POWERS OF THE PEOPLE (1996); and KEITH E. WHITTINGTON, CONSTITUTIONAL CONSTRUCTION: DIVIDED POWERS AND CONSTTTUTIONAL MEANING (forthcoming 1999).

228. See A NEW CONSTITUTIONALISM: DESIGNING POLITICAL INSTITUTIONS FOR A GOOD SocIETY viii (Stephen L. Elkin \& Karol Edward Soltan eds., 1993).

229. Karol Edward Soltan, What Is the New Constitutionalism?, in id. at 3, 3.

230. See Stephen L. Elkin, Constitutionalism: Old and New, in id at 20. Also exemplary in this regard is the important recent article by Michael C. Dorf and Charles F. Sabel, A Constitution of Democratic Experimentalism, 98 COLUM. L. REV. 267 (1998). 
or justify-it is to reach the best possible understanding of the distinctive political practice we call American constitutionalism.

\section{CONCLUSION}

It is both interesting and ironic that 1998 and 1999 saw a classic demonstration of constitutional change occurring outside the Supreme Court. I refer, of course, to the impeachment and trial of President Clinton. Constitutional scholars witnessed the only grand jury investigation aimed directly and exclusively at a sitting president and the only impeachment of a president initiated by a detailed report from an independent counsel.

There were numerous differences between the Clinton impeachment and the resignation of President Nixon, its closest analog in the post-New Deal period. The Nixon impeachment investigation established a number of constitutional practices that were not followed in Clinton's case. The House Judiciary Committee did not conduct a thorough investigation of the charges contained in the independent counsel's report and did not call material witnesses. ${ }^{231}$ Most important, Henry Hyde, Chairman of the Committee, deliberately decided to proceed in the absence of bipartisan agreement on the importance of the charges and the appropriate remedy for the President's misdeeds. ${ }^{232}$ As a final touch, the Senate decided to hold one of the few impeachment trials in American history without witnesses.

All of these events amounted to constitutional change from my point of view. It is perfectly possible that they will not outlast the turn of the century, given the public opprobrium heaped on the House impeachment managers. But they did happen and they could make a difference. In any case, they are now part of the constitutional landscape and deserve appropriate attention from scholars.

Whether they will receive it is an open question. To many legal scholars, I imagine the Clinton impeachment looked the stuff of pure politics. The events were related to constitutional provisions, to be sure, but they did not exactly constitute the stuff of normal constitutional science. From my point of view, that is all the more reason we should be interested in understanding the practices and fundamental political structures that made Clinton's impeachment possible. How has the constitutional system been affected by the politics of scandal? Why did so many firebreaks in the system seem to fail so consistently? Answering these questions requires not only an analysis of constitutional doctrine but also the kind of historical and

231. One difference that helped create those mentioned in the text was that the 1998 House Judiciary Committee was not representative of the House as a whole, while the 1974 Committee more closely resembled the membership of the House. See STANLEY I. KUTLER, THE WARS OF WATERGATE: THE LAST CRISIS OF RICHARD NIXON 479 (1990).

232. See id. at $480-505$. 
institutionalist approach I have advocated here. It requires seeing the Constitution as a whole. 
